\title{
Advances in the Household Archaeology of Highland Mesoamerica
}

\author{
David M. Carballo
}

Published online: 6 November 2010

(C) The Author(s) 2010. This article is published with open access at Springerlink.com

\begin{abstract}
Recent investigations and reconsideration of households in the Mesoamerican highlands illustrate the central role of domestic spheres of interaction to the broader cultural dynamics of the region over four millennia. Methodological advances in the analysis of past houses permit more sophisticated social reconstructions of the spaces and activities that constituted domestic life for the diverse peoples of the region. Current studies highlight the economic interdependence and diversification of households, their strategic flexibility in affiliation, the integrative ritual practices undertaken within domestic spaces, the material correlates of prestige competition between households, and the manner in which households articulated with a larger social universe.
\end{abstract}

Keywords Household · Domestic · Archaeology · Mexico

\section{Introduction}

The prehispanic households of highland Mesoamerica were as varied as the peoples and environments of this rugged landscape that comprises river valleys, lake basins, and high plateaus, separated by jagged mountains and snow-capped volcanoes. Highland Mexico was, and remains, home to the Aztec, Mixtec, Tarascans, Teotihuacanos, Toltec, Zapotec, and others. Household arrangements span a broad spectrum of size and composition, from nuclear families to remarkably large multifamily residences (compare Coupland and Banning 1996; Manzanilla 1996, 2009; McCaa 2003). The archaeology of highland Mesoamerica encompasses 3500 years of residential architecture and domestic practices, from modest

D. M. Carballo ( $₫)$

Department of Archaeology, Boston University, 675 Commonwealth Ave., Suite 347, Boston,

MA 02215, USA

e-mail: carballo@bu.edu 
wattle-and-daub houses of the earliest sedentary villagers to the lavish palaces of Aztec emperors on the eve of Spanish Conquest. Since highland cultures interacted frequently with one another and the rest of Mesoamerica, they shared conceptualizations of domestic arrangements and the practices undertaken within the confines of houses. Yet the temporal and spatial variability among households provide grist for comparison and cross-cultural analyses. Years of intensive research, well-preserved house remains, detailed ethnohistoric documents, and continuities in domestic lifeways observable in the ethnographic record combine to make the region an excellent setting for comparative study.

This article provides an overview of advances in household archaeology of the Mesoamerican highlands over the past 17 years, since the last of a series of seminal volumes by Flannery (1976), Manzanilla (1986), Wilk and Ashmore (1988), MacEachern et al. (1989), and Santley and Hirth (1993) appeared (for other comparative studies see Blanton 1994; Netting et al. 1984; Wilk and Rathje 1982). Central Mexico and Oaxaca receive greater attention because significantly more fieldwork has been conducted in those regions. A few select cases from western and northern Mexico also are included, since they represent equally important developments (Beekman 2010; Pollard 1997). The highlands of southern Mesoamerica are not included because they were part of a recent review of Classic Maya household archaeology (Robin 2003). A concise overview in Spanish of many similar issues is provided by Manzanilla (2007a).

Households may be defined along several axes: they are groups of individuals bound by some notion of kinship and shared identity who cooperate in the production and reproduction necessary for survival (Wilk and Rathje 1982); they are social units that structure human behavior but are also adaptable and can be reconstituted to meet the goals of their members (Rapoport 1969); and they serve as coordinated political actors that strategically negotiate their group's position within a social hierarchy (Bowser and Patton 2004; Lyons 2007). This review is organized to address how highland Mesoamerican archaeologists analyze and interpret past household activities within these axes of behavior. It follows a rough progression from relatively more internal to relatively more external dimensions of household activity, moving from what individuals make in their homes to how they affiliate as a group, how their rituals regenerate group ideologies, how they compete with one another, and how they articulate with a larger social universe. More specifically, I focus on how archaeologists in highland Mesoamerica are advancing understanding of (1) the sustained importance of households as diversified and interdependent units of economic production; (2) the ways in which households were socially constituted by individuals who used identity and affiliation in deliberately flexible ways; (3) the important roles of domestic rituals in socially integrating households and neighborhoods, while simultaneously offering possible venues for status differentiation; (4) competition between households for status and the multifaceted functions of palaces; and (5) transformations in domestic life associated with macroregional social changes such as sedentism, urbanization, and political evolution.

To situate these themes I first introduce the region, its peoples, and recent work by ethnographers and ethnohistorians, providing detail that is often absent in the 
material remains studied by archaeologists. I then cover the significant progress that has been made in the multidisciplinary methods of analyzing domestic contexts in the archaeological record.

\section{Highland Mesoamerica and its households in ethnography and ethnohistory}

The varied Mexican altiplano lies between the spines of the eastern and western branches of the Sierra Madre, an area that spans much of northern Mexico before converging at the southern Sierra Madre in the state of Oaxaca and terminating at the Isthmus of Tehuantepec (Fig. 1). Core areas of prehispanic civilization include (from south to north) the Valley of Oaxaca, a river valley approximately 1500 masl (meters above sea level) that is home to the Zapotec; the Mixteca, an adjacent mountainous region of canyons and pocket valleys closer to approximately 2000 masl and home to the Mixtec; central Mexico, a series of river valleys and lake basins (the largest is the Basin of Mexico, the location of modern Mexico City) more than 2200 masl, and home to the Aztecs, Toltecs, and Teotihuacanos; and the lake regions of West Mexico, including the Pátzcuaro Basin, which is also about 2200 masl and home to the Tarascans.

Mountain ranges in highland Mexico quickly climb from valley floors and channel human movement (Carballo and Pluckhahn 2007; Gutiérrez Mendoza et al. 2000). Climates are highly variable but are generally classified as temperate with arid, semiarid, or subhumid seasonal precipitation—wet summers and dry winters.

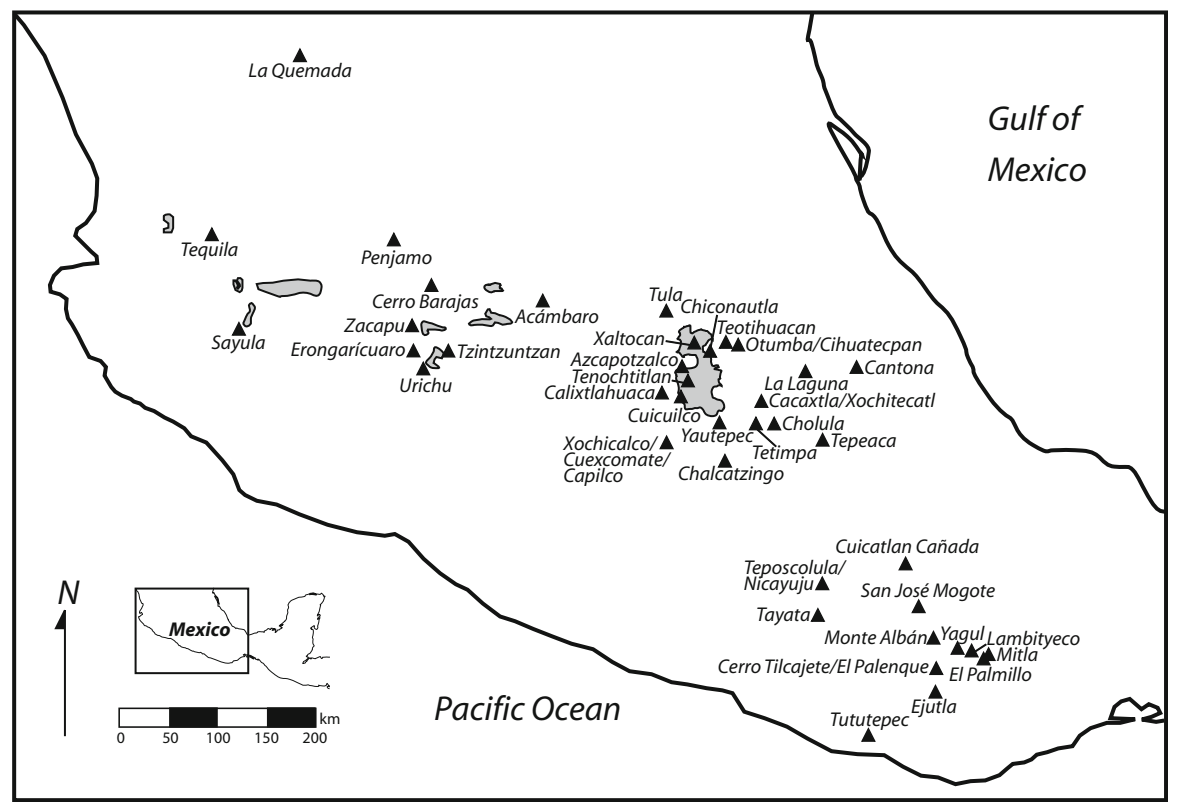

Fig. 1 Western Mesoamerica showing sites and regions mentioned in text. Lake systems are shaded. Map articulates with Robin (2003, Fig. 1) 


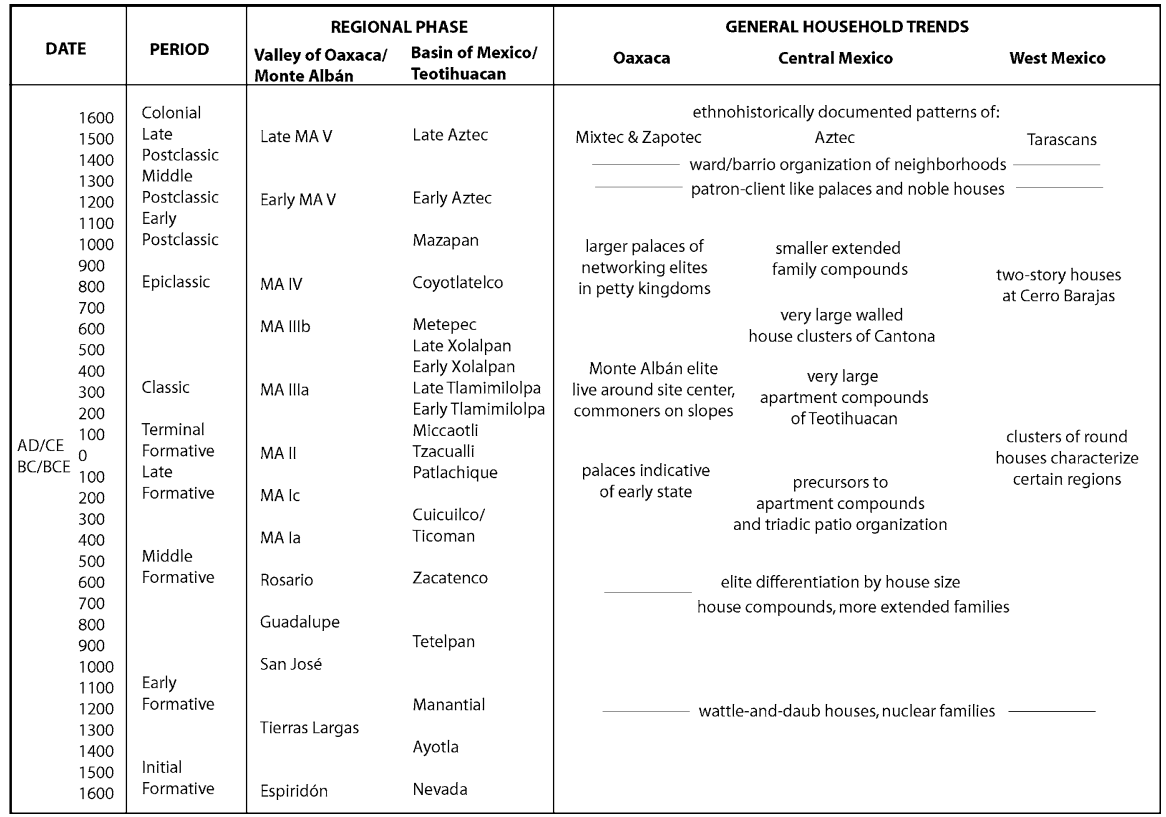

Fig. 2 Comparative chronology, drawing on Marcus and Flannery (1996, Table 3), Niederberger (1987, p. 43), and Rattray (2001, Fig. 1b)

Portions of southern central Mexico often receive double the annual rainfall of the Valley of Oaxaca and parts of northern central Mexico (approximately 1100 and $550 \mathrm{~mm}$, respectively; see Carrera-Hernández and Gaskin 2008). Culture-historical sequences are unique (Fig. 2) but can be generalized to include a Formative period of early sedentary villages evolving to cities (c. 2000-1 BC); a Classic period of complex state or imperial polities such as Teotihuacan and the Zapotec capital of Monte Albán (c. AD 1-700); an Epiclassic and Early Postclassic period of smaller kingdoms such as the Mixtec and expansionist states such as the Toltec (c. AD 700-1300); and a Late Postclassic period of empires including the Aztec, Tarascans, and Mixtec of Tututepec (c. AD 1300-1521). I retain the more conventionally used names for these cultures, which are a historical by-product of Spanish colonization having involved central Mexican allies, the creation of a capital for New Spain at Aztec Tenochtitlan, and a general bias to that region and Nahuatl, its dominant language. More accurate names for these cultures, in their indigenous languages, would be Didja Zaa for the Zapotec, Nuu Savi for the Mixtec, Hñähñu for the Otomi, and P'urhépecha for the Tarascans. The people we call Aztec identified themselves by many ethnic and political designations, with the dominant group calling themselves Mexica. We do not know how their predecessors in central Mexico, the Teotihuacanos and Toltec, referred to themselves.

Rich ethnographic and ethnohistoric records from highland Mexico allow archaeologists investigating earlier periods to evaluate the applicability of welldocumented social institutions from later ones. Such data must be used judiciously, 
however, and only when they may be reconciled with archaeological remains (see cautions by Cowgill 1997, p. 131; Feinman 1997; Marcus and Flannery 1994). As Marcus (2000, p. 232) notes, "The ethnohistoric and ethnographic data are too compelling to ignore, but their use requires discipline and a great deal of common sense." One undesirable consequence of the injudicious use of textual sources is the inaccurate portrayal of a prehispanic past full of unchanging social institutions extending from the Postclassic back to the Formative. Yet when mutually reinforcing lines of evidence are available, the critical evaluation of ethnographic and ethnohistoric sources for comparison to the archaeological record continues to be a productive means of formulating bridging arguments that connect static material culture to behavioral dynamics.

Several 16th-century documents from central Mexico detail aspects of Nahua and Otomi household organization during the first decades of the colonial period. Wright Carr (2008) has recently demonstrated how linguistic terms for families, households, neighborhoods, and other forms of social organization are conceptually parallel in these two indigenous groups, the largest in central Mexico at the time of the conquest. Primary-source documents include censuses recorded by Nahua scribes, writing in Nahuatl using the Roman alphabet, that assess tribute responsibilities (e.g., Carrasco 1964, 1976; Cline 1993). They also include hybrid codices, combining hieroglyphs with alphabetic glosses written by indigenous scribes trained in Spanish, that provide an invaluable native account of household composition, landholding, and arithmetic (e.g., Harvey 1986; Offner 1984; Williams 1984; Williams and Harvey 1997; Williams and Jorge y Jorge 2001). The most comprehensive early census information originated from relatively rural areas of the Aztec heartland, but the organization of households within the urban capitals of altepemeh (city states) is detailed by the works of other authors (e.g., Alcántara 2004; Calnek 1972, 1974, 1976, 2003; Caso 1956; Kellogg 1986; Smith 2008).

The accounts from central Mexico illustrate general tendencies for residences that could stand alone as isolated rural farmsteads or, more frequently, be connected as part of larger compounds that accommodate diverse social arrangements of families characterized by bilateral kinship, organized as both nuclear and joint households, and allowing for bilocal residence in the case of the latter, but with a preference for patrilocality. On the whole, women appear to have been subordinate to men, but they enjoyed greater gender equality than in many premodern societies because they could own land, will their property to their children, and initiate divorces from their husbands (Kellogg 1986; Schroeder et al. 1996; cf. McCaa 2003). These tendencies have endured in the household organization of contemporary Nahua communities in central Mexico, but the importance of bilateral kin ties and joint families has declined in favor of Spanish-style patrilineal, nuclear ones (Nutini 1968, 1996; Robichaux 1997). Robichaux (1997, p.161) proposes that the contemporary Nahua preference for male ultimogeniture in house ownership likely has prehispanic roots, which he suggests may have been a policy imposed by Teotihuacan or a later central Mexican state.

Prehispanic households articulated with their larger social universe through various collective organizations. Well-known corporate kin groups, such as the 
Aztec tlaxilacalli, calpolli, and chinamitl, the Mixtec sina, siqui, and dzini, or the mestizo term "barrio," represent an intermediate scale of social organization between the household and the community and were common throughout the highlands during the 16th century (Alcántara 2004; Calnek 2003; Lockhart 1992, pp. 59-93; Mulhare 1996; Restall et al. 2005, pp. 94-125; Terraciano 2001, pp. 102-132, 348). The significant regional variation in such terms makes it an exercise in futility to attempt any overarching model for the corporate structures of an entire ethnolinguistic group. For example, Alcántara Gallegos (2004, p. 188) distinguishes terms for corporate households and urban wards at Tenochtitlan that fit its particular metropolitan configuration, defining the calpolli (big house) as a social collectivity sharing a communal temple and the tlaxilacalli (house pierced by water) as an urban administrative unit that derived its name from physical boundaries involving canals or chinampas. One would expect variable usage of these terms in more rural settings. Scholars also have noted variability in social organization between the western and the eastern Nahua (both "Aztec"); the latter possessed certain institutions that were more similar to the Mixtecs and Zapotecs than to their ethnolinguistic counterparts to the west (Lockhart 1992; Pohl 2003). Yet the more important point is the frequent appearance of corporate and flexible suprahousehold organization in the highlands. Since native systems of land tenure included significant proportions of collective holdings, and land left untended was quickly redistributed by the community, household members strategized to keep and bequeath productive plots within corporate systems (Restall et al. 2005, p. 94).

Corporate kin groups in highland Mexico also were often organized around hereditary lords in patron-client relations involving rotary draft labor duties required of commoners - to work the fields of nobles and participate in public works - and reciprocal managerial obligations on the part of lords (Chance 1996, 2000, 2008; Terraciano 2001). Status inequalities were manifested in the size of households and their residential architecture. Higher-status families in central Mexico tended to own larger residences with more associated structures because they included more dependent nonkin, their children were less likely to move away, and they were more frequently polygamous (Carrasco 1964, 1976; Cline 1993; Evans 1989, 1991; Hicks 1986; Smith 1993; Smith et al. 1999; see also Netting 1982). Similar status divisions were present in Oaxaca, but certain differences existed in kinship organization, with the Mixtec being relatively more lineage- and noble-focused (Flannery 2003[1983]a; Kowalewski et al. 2009, pp. 337-345; Spores 1984; Spores and Flannery 2003[1983]; Terraciano 2001).

Archaeologists working in the highlands continue to draw on the ethnographic and ethnohistoric accounts of household organization and benefit tremendously by communicating with colleagues in related disciplines who are more intimately familiar with these rich data. In turn, the material focus and diachronic breadth of the archaeological record offer the best opportunities for documenting patterning and variability in the physical dimensions of past domestic lifeways and their development over time. "Households" as social units are not synonymous with "houses" as physical dwellings, but much of the variability in the former-whether the by-product of temporal change, status, urbanism, norms of affiliation, or other 
axes of variation-possesses a material component that may be reconstructed through careful excavation of the latter (Figs. 3 and 4). Advances in archaeological methods have made these reconstructions much more sophisticated.

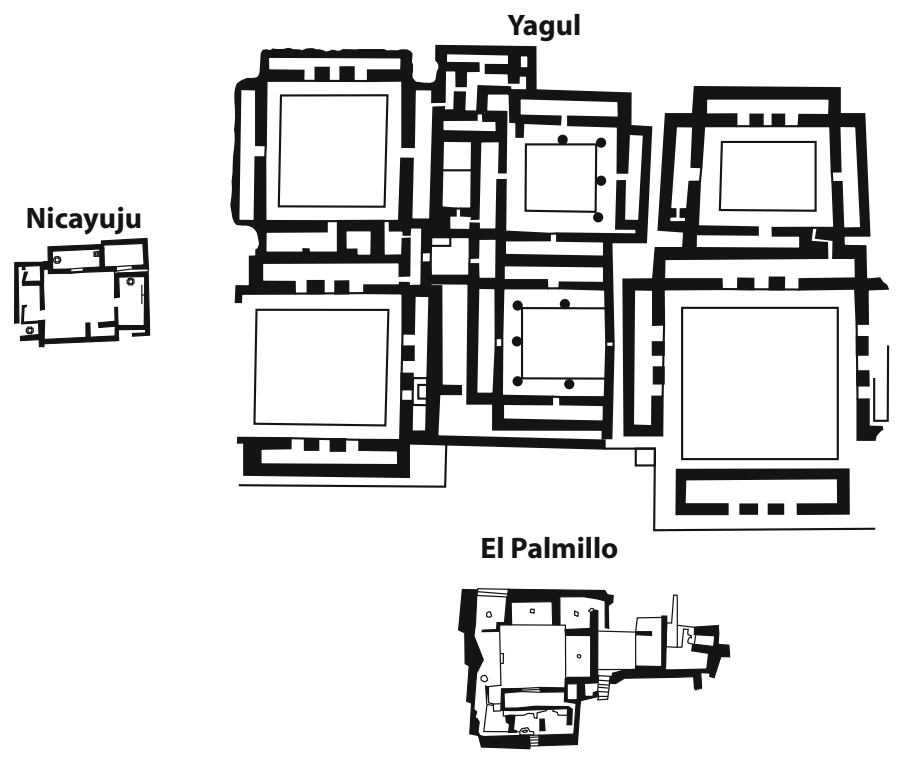

Monte Albán

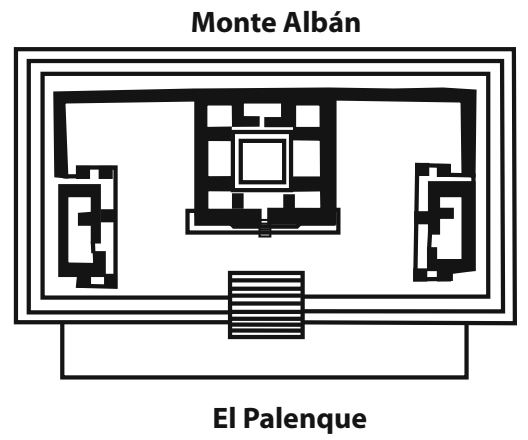

Tierras Largas
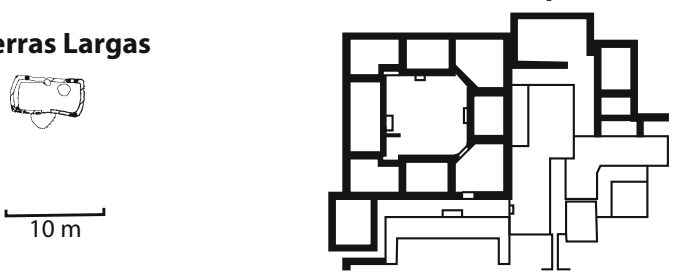

Fig. 3 Ground plans of prehispanic houses from Oaxaca redrawn and adapted from the following sources: Nicayuju house compound (Pérez Rodríguez 2006, Fig. 3); Yagul palace (Flannery 2003[1983]b, Fig. 8.28); El Palmillo palace (Feinman and Nicholas 2007b, Fig. 8.5); Monte Albán house compound (González Licón 2003, Fig. 6.10); Monte Albán palace (Winter 2003, Fig. 8.7); Tierras Largas wattle-and-daub house (Flannery and Winter 1976, Fig. 2.17); El Palenque palace (Spencer and Redmond 2004b, Fig. 6). Figure has a rough arrangement, chronologically and by status, with earlier houses at bottom and with commoner houses to left and palaces to right 


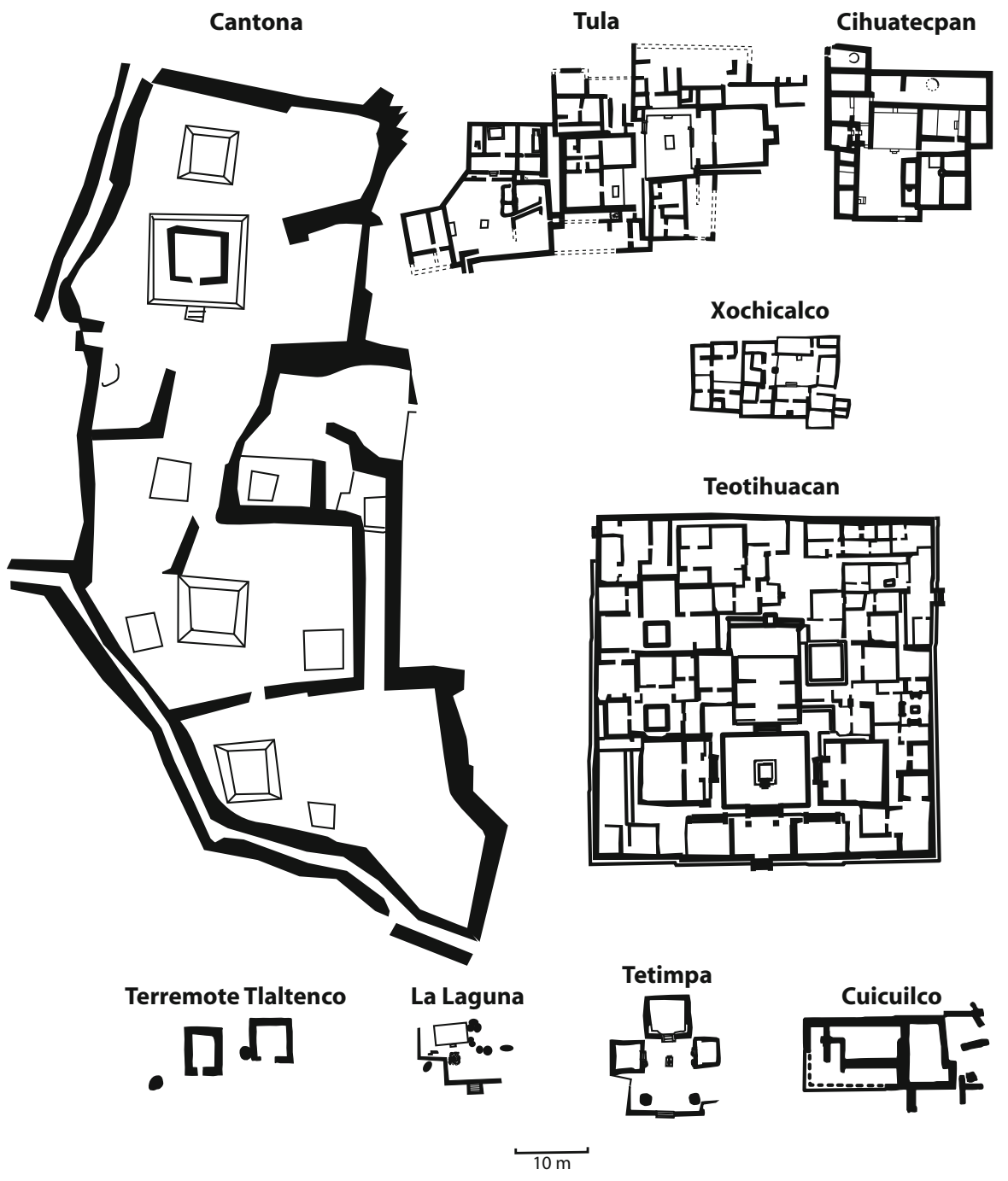

Fig. 4 Ground plans of prehispanic houses from central Mexico redrawn and adapted from the following sources: Cantona patio group (García Cook 2003, Fig. 5); Tula apartment compound (Healan 2009, Fig. 4.4); Cihuatecpan palace (Evans 1991, Fig. 3.10); Xochicalco house compound (Hirth 2000a, Fig. 7.5); Teotihuacan apartment compound (Manzanilla 1996, Fig. 7); Terramote Tlatenco wattle-anddaub houses (Serra Puche 1986, Fig. 10); La Laguna platform with wattle-and-daub house (Carballo 2009, Fig. 4); Tetimpa platform with triadic patio group (Plunket and Uruñuela 2003, Fig. 2.5); Cuicuilco house compound (Serra Puche 1986, Fig. 11). Figure has a rough chronological arrangement with earlier houses at bottom

\section{Contemporary methods of household archaeology}

Associated with recent commemorations of the prolific career of the late William Sanders, I recently viewed William Mather's movie footage of the Teotihuacan 
Valley Project's 1961-1962 excavation of an apartment compound at Maquixco Bajo. Other than the much higher incidence of DWS (digging while smoking), the basic field methods of establishing a grid over a domestic structure and removing sediment from it remain familiar half a century later. Not so for the multidisciplinary methods of quantifying artifact distributions, studying the material traces of past activities in house floors, and determining household composition. Remote sensing and GIS facilitate understanding spatial patterns in the distribution of houses and household assemblages. Residue and chemical analyses provide entirely new lines of data for reconstructing the activities that took place on floors within domestic spaces. Bone chemistry studies similarly afford new means of documenting the diverse migration histories that contributed to the continual remaking of households, particularly in the cosmopolitan urban centers of the highlands.

Remote-sensing techniques greatly assist the essential first step of household archaeology: locating houses and their associated domestic features. Although semiarid vegetation and certain building traditions (e.g., basal platforms and adobe or masonry walls) make houses conspicuous from the surface at many sites in the highlands, those with simpler architecture or deeper deposits remain invisible to the naked eye. Archaeologists have been successfully employing magnetometry, ground-penetrating radar, electrical resistivity, and other methods to document domestic structures and features, and to identify those that look promising for excavation (Álvarez Díaz 2009; Barba 1994, 2003; Barba and Pereira 2003; Hesse et al. 1997; Litvak et al. 1990; Pérez Pérez 2008). Even in Teotihuacan's conspicuous apartment compounds (Fig. 5), remote sensing has been used as a first step in mapping subsurface domestic contexts prior to the destructive and irreversible process of excavation (Barba 1993; Barba and Manzanilla 1988; Manzanilla and Barba 1994, pp. 19-42). Additionally, a suite of techniques was recently used by Robertson, Barba, and colleagues to identify simpler residences that lack surface visibility within that city's urban sprawl (Robertson 2008). Such structures housed the lowest-status families at Teotihuacan, making them an essential component in any reconstruction of residential patterns and social differentiation.

GIS applications help elucidate spatial patterning among houses and in the features and activity areas associated with them, thereby providing more quantitative data for defining neighborhoods, domestic production areas, and other household dynamics. Robertson has produced multiple choropleth maps based on Teotihuacan Mapping Project (TMP) collections. His analysis of San Martín Orange pottery distributions using Bayesian methods corroborates the location of zones of high consumption and/or production in districts located in northern and southern parts of the city, first suggested by members of the TMP (Robertson 1999). Robertson also used correspondence analysis to differentiate more private domestic contexts from more public ones based on spatial patterning in vessel forms that are, respectively, more conducive to storing or serving foods. Elaborating on this work, he has analyzed the structure of neighborhoods, demonstrating heterogeneity in social status within them; higher-status residences tended to be centrally located with respect to their neighborhood, and spatial segregation by status increased later in Teotihuacan's occupation (Robertson 2005, in press). 


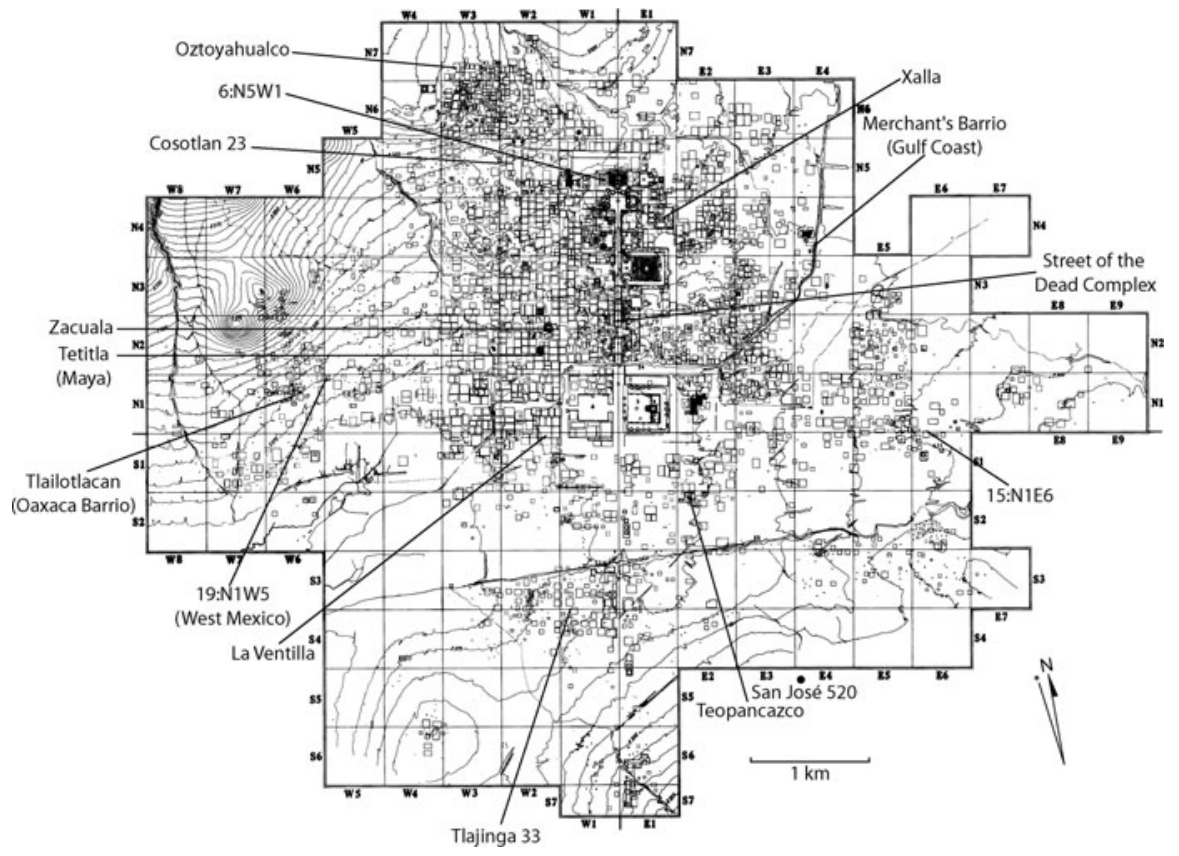

Fig. 5 Map of Teotihuacan depicting recent household excavations and other domestic areas mentioned in text. Map copyright René Millon. Used with permission

Spatial analyses of domestic assemblages represent a logical extension of the powerful analytical tools offered by GIS, but so far they have been underutilized in Mesoamerica. Excavations of Formative houses in Oaxaca set the standard of piece plotting artifacts on house floors (Flannery 1976; Flannery and Marcus 2005). Because of their earthen or sand floors, Formative houses or rural houses from later periods often contain artifacts trampled in the floor that can be spatially associated with activity patterns, in addition to those items left during abandonment. The work of Flannery and Marcus in Oaxaca was followed by other household excavations that encountered in situ artifacts left due to sudden abandonment and/or little postdepositional disturbance (e.g., Cobean and Mastache 1999; Healan 1989, 1993; Hirth 2006; Manzanilla 1985, 2007a; Manzanilla and Barba 1994, pp. 42-68; Plunket and Uruñuela 1998, 2003; Uruñuela and Plunket 1998; Webb and Hirth 2003). Although time consuming in the field, piece plotting artifacts provides essential spatial information for interpreting patterning in domestic activities. The technique lends itself particularly well to GIS applications, such as the contouring of artifact and ecofact distributions or other spatial analyses of occupation floors that can be expedited through photomapping (e.g., Aldenderfer 1998; Craig et al. 2006). These methods are helpful additions to the repertoire currently employed and should be applied to appropriate contexts in highland Mesoamerica.

Floor and soil chemistry studies have revolutionized household archaeology by providing supplementary lines of evidence to architecture and artifact distributions for discerning past activities in domestic spaces (Aguirre 2000; Aguirre and 
Quintana 1998; Barba 1990, 2007; Barba and Lazos 2000; Barba et al. 1987, 2007; Manzanilla and Barba 1990; Mejía Pérez Campos and Barba 1991; Ortiz and Barba 1993; Tovalín and Barba 1999). Not only are these methods valuable in contexts of complex habitations with long occupation sequences and meticulously swept living surfaces, as is usually the case at urban centers with lime-plaster floors, but also for simpler house types, shorter occupations, and contexts with in situ artifacts on earth or sand floors. In the case of the latter two, chemical studies corroborate whether artifact distributions reflect past activity areas or may be more attributable to the dynamics of house abandonment or postdepositional processes. In a pioneering application of soil chemistry, Hirth (1975) used relative phosphate concentrations for identifying residences at Manzanilla, Puebla, and Chalcatzingo, Morelos. Methods have been refined since then through ethnoarchaeological analysis of modern highland houses (Barba and Bello 1978; Barba and Ortiz 1992) and a range of comparative studies, making these techniques one of the more developed additions to household archaeology in the region. Studies undertaken thus far have documented food-production areas through elevated $\mathrm{pH}$ levels and have differentiated rituals involving bloodletting and the burning of copal through analysis of proteins and fatty acids; they also have distinguished heavily trafficked areas from resting or storage areas based on the relative concentrations of absorbed residues (see Barba 2007). Barba and colleagues (1999) suggest that elevated carbonates (such as calcium) in the floor of a room at Azcapotzalco may indicate the draining of lime-soaked water during the nixtamalization of maize.

Advances in bone chemistry studies using strontium, oxygen, and/or carbon isotope ratios have affected household archaeology as well. Comparison of ratios in teeth and bone has confirmed the migration of Zapotecs from Oaxaca to Teotihuacan, where they maintained elements of their original ethnic identity for centuries (Price et al. 2000; Spence et al. 2005). They also show the migration of individuals to Teotihuacan from other regions of Mesoamerica, likely including the Gulf Coast (Spence et al. 2004, 2005). Both analyses substantiate migratory patterns first inferred by other material remains (e.g., Rattray 1993, 2004) and attest to the multiethnic and polyglot households of Teotihuacan. Carbon and oxygen isotopic analyses of the Tlajinga 33 compound also identified migrants from West Mexico (White et al. 2004). By coupling DNA and artifact analyses, Paredes Gudiño (2005) describes waves of migration to Tula, leading to the creation of another multiethnic population.

At Teotihuacan, Tula, and other cosmopolitan centers of the highlands, the diversity of the population was mirrored by the craft activities that took place in their households. Researchers working in those cities and elsewhere in the region have documented the importance of intensive and diversified domestic production in both urban and rural settings, resulting in the rethinking of how prehispanic economies were organized. I now turn to these issues and other specific topics of highland Mesoamerican household archaeology that warrant the most attention based on the last 17 years of research. Following a progression from more internal to more external scales of analysis, I begin with domestic economy and move through the social composition of households, their rituals, status competition between them, and their transformations relating to macroregional social evolution. 


\section{Domestic economies}

Archaeologists agree that the household was the fundamental unit of production in premodern societies, but recent research in highland Mesoamerica makes this point emphatically and challenges many prevailing assumptions in the literature on economic specialization. Important themes for reconsideration include (1) the relationship between scale and loci of production, and (2) the variety and complexity of specialized production activities in which households engaged. In the first instance, domestic economies in the highlands included high-intensity production of craft items and other goods (Feinman 1999). In the second, households often undertook multiple, interrelated production activities (multicrafting) intermittently as a strategy of buffering risk through diversified involvement in several economic networks simultaneously (Hirth 2006, pp. 275-300). These new insights run counter to earlier models of the complexity of production activities, which envisioned households as loci of low-intensity production and general self-sufficiency, and highintensity production to have involved full-time specialists producing one type of good in nonresidential settings (e.g., Brumfiel and Earle 1987, pp. 4-5; Costin 1991, pp. 3-18; Lewis 1996; Peacock 1982; van der Leeuw 1977).

Archaeological models of craft specialization matured significantly in subsequent years to highlight differing strategies of individual artisans in production activities, the social value of craft objects, and how crafting can generate, reinforce, or challenge relations of power between individuals and groups (e.g., Brumfiel 1998, 2005; Costin 2001; Hruby and Flad 2007; Schortman and Urban 2004). Even so, much more attention has been focused on political economies at the expense of domestic economies, relegating the more common — some may say vital-activities of household production to a secondary status in the archaeological literature. Household research in highland Mesoamerica provides detailed cases of highintensity household production and the central role of intermittent (i.e., part-time) multicrafting to the robust trade networks and market economies of the region (Feinman 1999; Feinman and Nicholas 2000, 2004a, 2005, 2007a; Feinman et al. 2002, 2007; Hirth 1998a, b, 2006, 2009a, b; see also Shimada 2007). These authors suggest that for much of the prehispanic sequence following initial sedentism, intensive household production was stimulated by economic symbiosis and market demand rather than patronage or political command. While earlier Formative period elites may have been involved in craft activities (e.g., Marcus and Flannery 1996, p. 104), wealth in the urban state capitals of the later Formative through Postclassic periods likely was more land-based, and land-impoverished peasants turned to crafting for supplementary income (see Smith 1987; Smith and Heath-Smith 1994). As Hicks (1986, pp. 48-49) has noted, "The principal factors of production and sources of wealth and power in ancient Mexico were land and labor." When urban social elites and state political institutions became involved in craft production, they were more likely to tweak existing labor and tributary relations to their favor rather than radically orchestrating new ones. Crafting in elite households was almost entirely aimed at the production of sumptuary goods that symbolically reified elite power and prestige (e.g., Manzanilla 2007b, 2009) rather than at specialization in the production of objects for quotidian use. 
Formative domestic economies and multicrafting

Domestic multicrafting among households in Formative villages is documented by recent work in Oaxaca and central Mexico, though the degree of interhousehold specialization and exchange in these communities is currently less clear. Domestic craft activities at San José Mogote included the production of ceramic vessels, chipped-stone tools, ground-stone tools, baskets, textiles, mats, salt, shell ornaments, iron-ore mirrors, powdered pigment, and cut mica ornaments (Flannery and Marcus 2005, pp. 60-88). Two houses from the late San José phase show clear evidence of multicrafting (Flannery and Marcus 2005, pp. 314-319). Balkansky and colleagues (2009) suggest that while most households at the Mixteca Alta site of Tayata were involved in some sort of stone-tool production during the Early to Middle Formative, one extensively excavated house contained additional evidence of pottery and shell-ornament production. Some form of organization of production by neighborhood is suggested at Tayata based on the distribution of pottery kilns and manufacturing by-products. Using experimental archaeology and the directhistorical approach, Balkansky and colleagues argue that multicrafting developed as a household strategy within the macroband societies of Oaxaca during the Archaic to Early Formative transition.

The work at San José Mogote and Tayata underscores the importance of horizontal excavations for understanding diversity in domestic economies, as production activities are often spatially segregated. The archaeology of Formative households must include the excavation of large areas external to houses (house patios and yards), where much of the production evidence is recovered, as also was the case for Classic period sites such as Ejutla (Balkansky et al. 1997).

Excavations in the Tepeaca region of Puebla suggest that early households there were neither small nor economically self-sufficient. Castanzo and colleagues have documented domestic pottery and lime kilns spanning the Formative sequence (Castanzo 2009; Castanzo and Anderson 2004). They suggest that domestic production beyond the needs of households was not stimulated by marginal land or overpopulation, since population estimates for the Tepeaca region are significantly below estimated capacity, but rather by the desire to acquire other goods and products from different households and communities.

The sustained, extensive excavation program and excellent preservation of houses at Tetimpa, Puebla, allowed Uruñuela and Plunket (1998) to document greater spatial differentiation in the use of structures on top of elevated platforms compared with patio floors, where a majority of the household's domestic production was undertaken. Although trash accumulated and was burned around the basal platforms of Tetimpa's patio groups, Uruñuela and Plunket documented relatively light concentrations, suggestive of more distant trash disposal and partial household assemblages even at the best preserved sites. Combining mortuary analysis, artifact analysis, and chemical sourcing, Plunket et al. (2005) propose that Tetimpeños were organized into senior and junior lineages that pooled economic resources.

Domestic multicrafting is apparent near the Formative center of Xochitecatl, Tlaxcala (Serra and Lazcano 2006, 2008). Late Formative inhabitants of a relatively 
modest house in Nativitas, east of the ceremonial core and with no direct connection to the elites residing there, produced jade beads and earspools-two prototypical prestige adornments in Mesoamerica (Hirth et al. 2009). The production sequence involved the specialized manufacture of the chert drills used as perforators and the basalt abraders used as polishers. Hirth and colleagues favor a consignment model of production, potentially involving elite procurement of the distant trade material but indirect supervision of manufacturing in a manner consistent with tequitl-like labor tribute. They reason that the two most compelling scenarios for the production activities-complete independence or consignment rather than direct elite oversight-imply the early prevalence of intermittent domestic multicrafting in the highlands, where even prestige goods were produced in a quasi-independent fashion. Greater independence in domestic production should be expected for utilitarian goods such as obsidian that was so abundant for households, particularly in central Mexico and West Mexico (Darras 1999, 2009; De León et al. 2009; Hirth and Flenniken 2002).

\section{Economic symbiosis and exchange}

In the middle of the last century, Sanders (1956) underscored the importance of economic symbiosis to highland Mexican economies and the mechanisms by which goods moved between the diverse resource areas of the highlands and lowlands. The volcanic, semiarid highlands offer obsidian and basalt for producing cutting and grinding tools, respectively, and xerophytic plants such as agaves (maguey) and prickly pear cacti (nopal), which would have provided a range of useful products. These plants are more evenly distributed than obsidian throughout the landscape, and usually two or more species were readily available to households in any particular community. The products extracted from xerophytic plants are highly perishable; therefore, archaeologists commonly reconstruct their economic significance indirectly through the nonperishable tools used to exploit them. Volcanic stone (particularly obsidian) and iron ore (which was polished into mirrors) are durable highland products that have frequently been used in reconstructing highland-lowland exchange (e.g., Pires-Ferreira 1975). Highlanders exchanged these goods as well as products derived from xerophytic plants for resources native to the lowlands - especially perishable cacao, cotton, rubber, tropical birds and their feathers, and nonperishable shell and jade.

Recent work in Oaxaca by Feinman and Nicholas illustrates this highlandlowland exchange and the importance of household production in great detail. Multiple excavation seasons and large horizontal exposures allowed them to reconstruct domestic shell-ornament manufacture and pottery production at Ejutla, and stone-tool knapping and xerophytic plant processing at El Palmillo (Balkansky et al. 1997; Feinman and Nicholas 1993, 1995, 2000, 2004a, b, 2005, 2007a; Feinman et al. 2001, 2002, 2007). Building on ethnoarchaeological studies by Parsons and Parsons (1990), Feinman and Nicholas document the importance of products derived from maguey (Agave spp.), nopal (Opuntia pilifera), and yucca (Yucca periculosa) to residences on the terraced slopes of El Palmillo. The fibers and fermentable sap of these plants were extracted and processed using tools made 
by households from local chert, representing another form of craft specialization in the community. The prized red dye cochineal, from the desiccated bodies of female Dactylopius coccus Costa insects inhabiting nopal, is less archaeologically conspicuous, though potentially much more important to the domestic economy of El Palmillo or other highland communities with abundant nopal.

Another important corridor for exchange between the highlands and the lowlands is the Sayula Basin in Jalisco. That households were engaged in agave processing is not surprising in this modern tequila heartland, but lake-bed salt processing documented by Liot et al. (2007) was a more important facet of the prehispanic domestic economy. Salt was exchanged together with nearby obsidian for coastal shell and other resources during the Epiclassic and Early Postclassic periods. Salt from lakeshores also was an exportable commodity for households in the Basin of Mexico (De León 2009). In general, highland lakes provided myriad economic niches for households around them (Parsons 2006). Lake systems were larger and more abundant during prehispanic periods; many have dried up completely in meeting modern Mexico's water needs (Serra Puche et al. 2004).

Away from lakes, maguey processing was a major component of household economies in central Mexico. The household organization of maguey processing at Cihuatecpan is detailed by Evans $(1989,2005 a)$ through the excavation and analysis of assemblages from seven houses. Evans notes that the diversity of potential maguey products and the year-round tending and processing of the plant required the coordinated efforts of several cooperative adults and would have encouraged extended families to reside in joint households. Specialized maguey processing involved important economic activities for female members of households, particularly weaving, and would have likely contributed to economic partnerships and greater gender equality between men and women (Evans 2005a; cf. Ember 1983). Both Evans and Nichols, who analyzed maguey-processing tools from Otumba (Nichols et al. 2000), connect the intensification of xerophytic plant use in the northeastern Basin of Mexico with population growth during the Postclassic.

Bonafil Olivera (2005) describes a range of artifacts associated with maguey processing and other forms of domestic production at the Epiclassic community of La Mesa in the Tula region. Fournier García (2007) also documents the importance of the plant in the arid Mezquital Valley near Tula, where exploitation of maguey is not only documented in her excavations of prehispanic houses but also in her ethnoarchaeological study of multicrafting in Otomi families. Maguey processing figured prominently in the domestic economies of the contiguous settlement of Cacaxtla-Xochitecatl-Natavitas during the Formative and Epiclassic periods (Lazcano Arce 2007; Lazcano Arce et al. 2006; Serra Puche and Lazcano 2006, 2008; Serra Puche et al. 2000). While many researchers have inferred sap extraction for fermenting pulque (based on the presence of chipped-stone scrapers) and maguey roasting (based on botanical remains found in pit ovens) (e.g., Carballo 2009; Haines et al. 2004; Parsons and Parsons 1990), the work of Serra Puche and Lazcano has the potential to overturn existing orthodoxy regarding alcohol in the pre-Columbian Americas if, as they claim, it involved distillation (cf. Bruman 1935). Serra Puche and Lazcano (2006, pp. 78-79) identify ceramic vessels with open bottoms and restricted spouts that they contend were placed over heated basins 
to trap the condensed distillate of roasted maguey to produce mezcal. If confirmed, this distilled beverage would have lasted indefinitely and, with its potency to volume ratio, would have been extremely well suited to long-distance trade. Yet the idea will remain controversial until more cases are documented and additional supporting lines of evidence are presented.

Household production in urban and imperial economies

Multicrafting and domestic economies of scale are clearly documented at Teotihuacan by the work of Cabrera Castro and Gómez Chávez 2008, p. 77; Cabrera Castro 1996, 1998; Gómez Chávez 2000) at the La Ventilla barrio, who recovered evidence of production activities involving obsidian, greenstone, bone, shell, slate, mica, pyrite, and semiprecious stones from a series of related apartment compounds (see Fig. 5). Manzanilla (2006, 2007b, 2009) details craft items produced at the Teopancazco and Xalla compounds, including sumptuous garments such as the zoomorphic headdresses depicted in the city's murals. These would have involved the coordination of multiple production activities to create a composite finished product-including pelt curing, feather working, and sewing or adhering shells or colorful stones. The work of Cabrera Cortés (2006) at Site 520, southeast of Teotihuacan, documents domestic pottery production by a household at the low end of the socioeconomic hierarchy. While the residents of the site inhabited the types of "insubstantial structures" under study by Robertson (2008) — made of uncut stone, adobe, and perishable materials - Cabrera Cortéz recovered burial offerings indicating that these individuals were integrated into Teotihuacan's urban economy. The inhabitants of Site 520 likely exchanged the ceramics they produced in return for goods produced by other Teotihuacano households and for items imported into Teotihuacan.

Sullivan $(2005,2006,2007)$ has investigated two production contexts at Teotihuacan that illustrate the intersection of independent household production, larger corporate entities, and state labor tribute. Sullivan's statistical analysis of pottery from Tlajinga suggests that the utility ware San Martín Orange-popular during the later Xolalpan and Metepec phases of the city's occupation-was produced by individual households cooperating as part of a larger ward/neighborhood collective, as does her analysis of figurine and censer production at Cosotlan 23. San Martín Orange vessels appear to have been used in both residential and state storage. Iconographically rich censers produced in large quantities in a state workshop in the Ciudadela were used in domestic contexts but contain a mix of symbols linked to state ideologies of warfare and fertility (Múnera Bermúdez 1985; Sugiyama 1998). Accordingly, Sullivan's investigations illuminate the types of households that likely fulfilled coatequitl-like labor duties for the Teotihuacan state through crafting at workshops attached to public structures on certain occasions, while carrying out their independent production activities at home (as was suggested by Millon 1992, p. 377).

Hirth (2006, 2009a) documents extensive domestic multicrafting during the Epiclassic period at Xochicalco, where five or six production activities were undertaken by the members of a single household. The diversity and high intensity of domestic production in Aztec communities is documented by Charlton and 
colleagues (1991) at Otumba, by Smith and colleagues at four sites (Calixtlahuaca, Capilco, Cuexcomate, and Yautepec) (Smith 2004b; Smith and Heath-Smith 1994; Smith and Lind 2005; Smith et al. 1999), and by Brumfiel and colleagues at Xaltocan (Brumfiel 2005; De Lucia 2007). Domestic excavations at three of the sites excavated by Smith and colleagues in Morelos-Capilco, Cuexcomate, and Yautepec-represent different tiers within a regional settlement and administrative hierarchy, demonstrating how household production varied in this sector of the Aztec world system. The authors document domestic craft production at all three sites, but economic diversification was greater at the regional center of Yautepec and more focused on cotton textiles in the smaller two (Smith 2004b). While greater diversification at Yautepec is not particularly surprising - given its larger population and the developed market system of the Aztec (Smith 2004a) — the second pattern runs somewhat counter to textual sources that report textile production in elite houses by commoner women as a form of labor tribute. Smith attributes intensified textile production to market forces in the two rural sites prior to Triple Alliance imperial expansion, and the continuation of household production following expansion to a combination of market, local elite patronage, and imperial tributary demands. In related work, Brumfiel $(1998,2006)$ examines the role of women in Aztec weaving and the decrease in social value of the practice in sites paying tribute to the Triple Alliance.

Levine (2007) considers the relationship between the domestic economies of commoner households and the imperial political economy at the Mixtec site of Tututupec - a lowland site founded by highlanders. His excavations suggest that commoners enjoyed a relatively high standard of living as a result of imperial policies and were therefore likely supportive subjects. Levine's household analyses focus on more bottom-up processes of social integration, raising questions for models in the archaeology of ancient states that are overly reliant on exploitation and coercion. Finally, recent work on the Tarascan empire is helping differentiate domestic economies from the political economy of one of the most centralized polities to have arisen in Mesoamerica. While strong political oversight appears to have characterized most of Tarascan metallurgy, pottery production was likely organized at the household and neighborhood levels, motivated more by market demands (Hirshman 2008; Maldonado 2008).

Recent literature from highland Mesoamerica underscores the vital role of domestic economies and the interdependence of households as social and economic units. Watanabe (2007, p. 304) has commented on why households are intrinsically interconnected with others:

[B]y its very existence, any household already presupposes other households on which it must depend. At the very least, incest prohibitions and an often gendered division of labor mean that households must acquire spouses from other households. The resulting marriage exchanges stimulate production and consumption beyond autarkic household levels while also enmeshing households in webs of ritualized reciprocity.

Accordingly, the relationship between domestic economies and household composition should be viewed as recursively entangled. Individuals adopt and 
modify forms of familiar organization that meet their social and economic needs and wants, the pursuit of which are, in turn, shaped by the structure of the household group within which they cooperate. Highland Mesoamerican households often displayed flexibility in composition to accommodate diversified domestic economies. This facet of the literature is reviewed in the following section.

\section{The social constitution of households and neighborhoods}

Mesoamerican archaeologists have been questioning earlier assumptions regarding how households and neighborhoods were socially constituted. Recent studies emphasizing individual agency within corporate domestic groups and the strategic use of social identities have resulted in a productive literature on the dynamics of house societies (the société à maison envisaged by Lévi-Strauss 1982, 1987). The recent focus on house societies has involved increased attention to the physical house, its heritable material possessions, and the flexibility of using multiple, seemingly opposed strategies of descent and affiliation to maintain titles, prerogatives, land, buildings, and other forms of wealth. Traditional axes for studying household identities, such as lineage and status, are complemented by consideration of the creative and regenerative nature of domestic practices performed in houses by multiple classes of agents, including different age grades and genders. Attention to these issues defines what I refer to as the "house society model," a perspective that emphasizes adaptability rather than a rule-bound adherence to cultural norms (see contributions in Carsten and Hugh-Jones 1995; Joyce and Gillespie 2000). Gillespie (2000) and González-Ruibal (2006) provide useful archaeological correlates for defining extended "house" versus lineal "kinship-based" societies.

\section{House societies}

Although originally applied to intermediate-scale social organizations-also called transegalitarian societies_both Monaghan (1996) and Gillespie (2000) argue for the applicability of the house society model for societies throughout Mesoamerica, including states and empires. The model is therefore reconcilable with the forms of corporate-kin organization that mediate between nuclear families and large, socially differentiated communities, such as the ethnohistoric examples discussed earlier. While it is possible that Mesoamericans were somewhat more house-oriented than other portions of the ancient world, use of house societies as a generalized model runs the risk of obscuring important variability across Mesoamerica. Individuals in all societies place relative emphases on descent and affiliation as well as on residence rules and practical activities in defining their households (van den Berghe 1979; Watanabe 2004). The important issue is how people differed in these dimensions over space and time.

Mesoamerican ethnohistorians point to a constellation of relative degrees of corporateness and flexibility of affiliation among societies, with the 16th-century Aztec, Mixtec, and Maya generally classified along different points of a continuum 
and more or less in decreasing order of adherence to these strategies (Lockhart 1992, p. 59; Restall et al. 2005). Terraciano (2001, pp. 349-350) contends that the Maya cah represents a very different form of household organization and is more lineage- or descent-based compared to the Nahua (Aztec) calpolli and Mixtec siqui. It does not follow that the members of lowland Maya households were any less strategic than the members of highland Mexican households. Rather, during the colonial period households in central Mexico and the Maya lowlands are likely to have strategized differently, both structured by and regenerating the norms of residence, inheritance, descent, and affiliation that connected their members together and defined the households they interacted with as separate entities. Variability in strategies of affiliation also existed within regions, such as the relatively greater focus on lineage estates by the eastern Nahua compared to the western Nahua (Pohl 2003). House systems in the enduring small states of Mesoamerica, such as the Classic Maya and Classic to Postclassic Mixteca-Puebla interaction sphere, may have been more of a phenomenon associated with an aristocracy of noble houses, while those of large, corporate central Mexican states, such as Teotihuacan and the Mexica-Aztec, spanned more of the socioeconomic spectrum (see Kowalewski et al. 2009, pp. 340-341).

The saying "all politics is local" could be reduced even further to "politics begins in the household." Coupled with domestic production, politics and economy provide two variables that radiate out from households to structure neighborhoods and communities and, in turn, shape households as participants within these larger spheres of interaction. Within their respective continua of variability, the relative degrees of collectivity in political strategies (e.g., Blanton and Fargher 2008; Blanton et al. 1996; Feinman et al. 2000) and commercialization in an economy (e.g., Smith 2004a) appear to covary with household composition in Mesoamerica. As a working hypothesis, I propose that Mesoamerican households were more likely to be organized as house societies in times and places when political systems were more corporate and/or economic systems were relatively more commercialized, encouraging migration and ethnic diversity. More exclusionary political systems and/or less commercialized economies may covary with house societies that are based on noble genealogies, patron-client relations, and aristocratic houses.

Since ethnohistoric and archaeological cases show that extended-family households were a central feature of prehispanic societies in the Mexican highlands, the evolution of corporate domestic groups inhabiting shared house structures and the potential variability between them relative to community size represent central topics in the household archaeology of the region. At Chalcatzingo, Grove and Gillespie (2002) analyzed architecture and mortuary practices in proposing that individuals were organized into houses as early as the Middle Formative. This early instance is temporally bookended by Perkins' (2005) proposal that early colonial tecalli (patron-client-like "lord-houses") in Puebla also were organized as house societies. These cases span more than two millennia of culture history. Central Mexican societies seem to conform most to the house society model throughout much of the prehispanic sequence (Chance 1996, 2000), and the region was certainly home to the most corporate and bureaucratized political systems, as well as the most commercialized economies. Yet interesting variability did exist, such as 
between the Postclassic eastern and western Nahua; the reasons for it are worth exploring.

The organization of houses and neighborhoods

The multifamily apartment compound of Teotihuacan is one of the most densely populated residence types of the ancient world, with dozens to as many as 200 individuals living in a single compound (Fig. 6, bottom) (Manzanilla 2009). The inhabitants of Teotihuacan's apartment compounds cooperated in economic activities and shared flexible and highly varied kinship ties. Cowgill (2008, pp. 91-95) estimates that 2300 apartment compounds of variable size were occupied during Teotihuacan's height, with a median architectural footprint of $1830 \mathrm{~m}^{2}$. Teotihuacan neighborhoods consisted of several associated compounds and may have been the size of large villages or small towns, inhabited by between 1500 and 2000 people (see also Cowgill 2007, p. 279). Plunket and Uruñuela (1998, 2002; Uruñuela and Plunket 1998, 2007) have convincingly demonstrated that the central organizing feature of apartment compounds - a triadic arrangement of talud-tablero structures around an open patio with central altar-has its earliest documented manifestation in the patio groups of the southern Puebla-Tlaxcala region, in Late and Terminal Formative communities such as Tetimpa. Yet they view lineage, materialized in the burials placed within talud platforms, as the more important organizing principle for Tetimpa's households. How, then, did the exceedingly corporate and collective Teotihuacano apartment compound evolve?

Plunket and Uruñuela $(2003,2005,2006,2008)$ document the residential abandonment at Tetimpa as a result of Popocatepetl's eruption c. AD 50. They suggest that people migrated from Puebla-Tlaxcala to Teotihuacan and Cholula, introducing elements of their domestic styles and lifeways to these growing, cosmopolitan cities (see also García Cook 1981). Teotihuacano apartment compounds possess both the patio-group arrangements that were prevalent earlier in Puebla-Tlaxcala and the rectilinear connected room blocks seen earlier in the Basin of Mexico at Cuicuilco and Loma Terramote (Santley 1989, 1993; Serra Puche 1986). Following the intense nucleation of multiethnic populations at Teotihuacan, lineages may have coalesced into larger corporate entities with communal land ownership, occupational specialization, and shared veneration of ancestors and patron deities centered at domestic shrines, similar to the Aztec calpolli. Unfortunately, we know little about the earliest domestic architecture of urban Teotihuacan, but the importance of physical houses, economic functions, and compositional flexibility of apartment compounds are well documented from the midportion of the city's history until its collapse.

The earliest dated apartment compounds correspond to the Early Tlamimilolpa phase (third century AD), when a major building initiative was undertaken by Teotihuacan's inhabitants to create formal residences conforming to an urban grid that, in turn, were organized into distinct walled neighborhoods. The large population who erected the city's pyramids and central structures certainly lived around them, but later construction razed these earlier houses. Millon (1981, p. 208) noted a paradox of the Teotihuacano compound: they were highly inflexible 

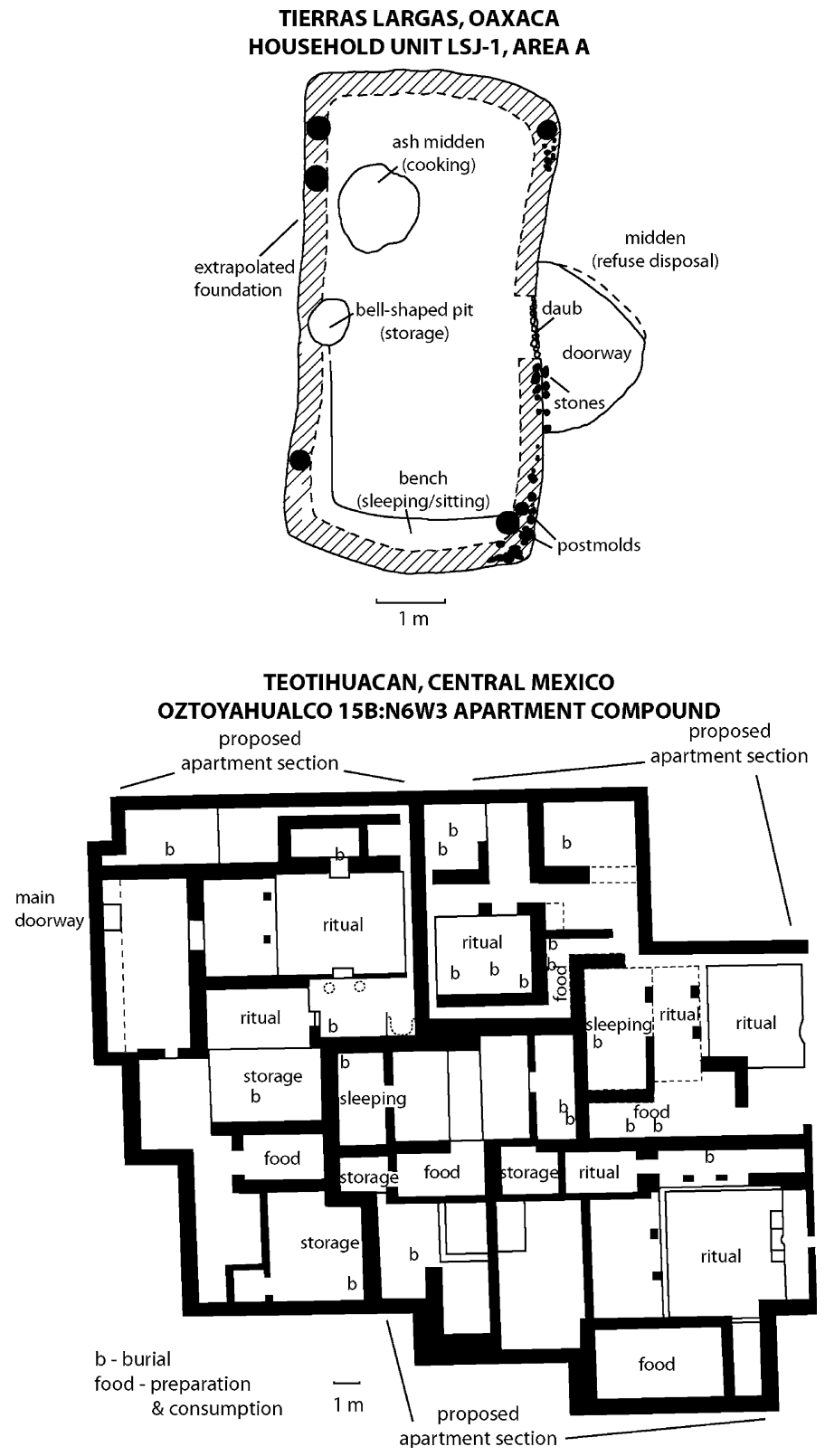

Fig. 6 Two extensively and meticulously excavated houses. The house from Tierras Largas dates to the Late San José phase (c. 1000-850 BC) and was a wattle-and-daub construction that likely housed a nuclear family (redrawn and adapted from Flannery and Winter 1976, Fig. 2.17). The house floor provides an excellent example of the careful piece plotting of artifacts. The Teotihuacan apartment compound dates between the Late Tlamimilolpa to Late Xolalpan phases (c. AD 300-500) and was a concrete and lime-stucco construction that likely housed separate families in three partitioned sections (redrawn and adapted from Manzanilla 1996, Fig. 7). A multidisciplinary research program, including floor chemistry studies, generated a wealth of information on Teotihuacano domestic life 
architectural units-built in single, coordinated episodes, with little possibility of tacking on additional rooms - inhabited by extremely flexible social units, for which malleability was a virtual necessity. He suggested that the evolution of the apartment compound during the middle of the city's history was a strategy by its rulers to administer corporate kin groups for the purposes of taxation and labor recruitment, citing the fact that the residence type did not survive the collapse of the state (Millon 1981, p. 209). Building on Millon's arguments, Kurtz and Nunley (1993) argued that apartment compounds were part of an effort to inculcate an ideology of work through hegemonic, but not coercive, processes, such as the de-emphasis on individual achievements and subordination of individuals to gods, natural forces, and social roles in the city's art.

Whether by state imposition or local adoption, the apartment compound became a common residential structure throughout Teotihuacan's inner political realm, with excavated examples reported from rural sites in the Teotihuacan Valley (Charlton et al. 2002), possible secondary administrative centers in the Basin of Mexico (García Chávez 1998; Pérez Negrete 2004), and adjacent regions, including northwestern Tlaxcala (Martínez Vargas and Jarquín Pacheco 1998) and southern Hidalgo (Díaz 1981). Material remains, including the bone chemistry studies described previously, document ethnic diversity within neighborhoods and even within apartments, with migrants potentially having arrived from Michoacán, Oaxaca, Veracruz, and the Maya region (Gómez Chávez 2002; Gómez Chávez and Gazzola 2007; Manzanilla 2009; Price et al. 2000; Rattray 1993, 2004; Spence et al. 2004, 2005; Taube 2003; White et al. 2004).

The best evidence for flexibility in kinship and affiliation in Teotihuacano apartment compounds, in a manner consistent with the house society literature, comes from the recent work of Spence and colleagues (2005). Although there appears to have been a greater tendency for patrilocal residence, these authors document that the inhabitants of the Merchant's Barrio were matrilocal, with foreign men having married into houses primarily organized by local women from Teotihuacan. Spence (1974) had suggested manipulability in apartment composition much earlier, based on morphological features in one apparent matrilocal sector of the La Ventilla B compound. If accurate, these cases represent one of the most compelling archaeological instances of strategic flexibility in household composition, in the absence of textual evidence. It appears that if there was an open economic niche at Teotihuacan, norms of residence and affiliation could be tailored to fill it. The applicability of the house society model at Teotihuacan also is apparent in the physical layout of neighborhoods, which included such integrative constructions as shared temple structures and areas for playing the ballgame (Gómez Chávez et al. 2004; Manzanilla 2007b). In this sense, Teotihuacano neighborhoods were similar to documented Aztec examples (e.g., Smith 1993), having served as loci for communal rituals and leisure activities such as sports and the board game patolli (Cabrera Castro 1996, 1998; Escalante Gonzalbo 2004; Manzanilla 2006, 2009). Residences were never as populated elsewhere in Mesoamerica as they were at Classic period Teotihuacan, but neighborhood organization and nucleated, extended-family houses were common in the highlands. I first look at other parts of central Mexico before turning to Oaxaca and West Mexico. 
The residents of Cantona were densely nucleated during the Classic and Epiclassic periods, which García Cook (2003) suggests was a strategy for resisting Teotihuacano expansion through the central highlands. They lived in spacious, enclosed patio groups with stone house platforms and encircling walls that were separated by paved, serpentine thoroughfares, suggesting that defense and safety were concerns (García Cook and Merino Carrión 1998). Cantona's inhabitants were organized into neighborhoods, many of which maintained their own temple and ballcourt complexes. García Cook (2003, p. 319) reports that the average nonelite patio group at Cantona covers $900 \mathrm{~m}^{2}$, ranging from 306 to more than $2000 \mathrm{~m}^{2}$, similar to Teotihuacan apartment compounds but more dispersed in their interiors. He suggests that families at Cantona would have kept small internal gardens and penned turkeys and dogs, contributing to the large size of their enclosures. García Cook notes that elite patio groups are slightly smaller in total area but have singlehouse platforms that were considerably larger than any found in nonelite groupings, made of more elaborate construction materials, and with close associations to civicreligious complexes. If correct, the possibility that Cantona's elites lived in nuclear families as opposed to nonelite extended families (García Cook 2003, p. 319) departs from the expected relationship between household size and status (e.g., Carrasco 1964, 1971, 1976; Hirth 1993a; Netting 1982; Smith 1987).

Hirth (2000a, b, 2003) identifies 14 urban subdivisions at Xochicalco and equates them with the chinamitl of early colonial Morelos, which were smaller units (approximately 200-300 individuals) than the calpolli or tlaxilicalli of Postclassic and early colonial centers in the Basin of Mexico. The fact that Xochicalco's urban core included six separate fortified precincts suggests a segmental organization and that the city likely formed following a confederation of independent units that came together for purposes of mutual defense and offense (Hirth 2003). Accordingly, behavioral flexibility and corporate factionalism were not only characteristics of highland households but also of suprahousehold units that together created communities.

The inhabitants of Tula lived primarily in two types of residence: house groups (or house compounds) and apartment compounds. The two are distinguished by their size. House groups consist of attached structures, sometimes enclosed by walls, housing approximately three nuclear families; apartment compounds are larger than house groups but generally smaller than their Teotihuacano counterparts (Cobean and Mastache 1999; Healan 1989, 1993, 2009; Mastache and Cobean 2003; Mastache et al. 2002; Paredes Gudiño 1990). House groups at Tula are similar to the patio groups, or solares, common throughout Mesoamerica but, as in Cantona, usually possess more substantial connecting walls that bind architectural elements more closely than those types in more rural settings (see Healan 2009). The two forms may represent ethnic divisions at Tula since an earlier site in the area, La Mesa, has only patio groups; Bonafil Olivera (2005) connects this form to a northwest Mexican tradition distinct from apartments of the Basin of Mexico. It is possible that the house group at Tula represents an elaboration on this tradition for a more urban context.

Neighborhood or ward organization has deep roots in Oaxaca as well. It was clearly present during Monte Albán's initial urbanization during the Late Formative 
and possibly dates to the Early Formative at San José Mogote (Feinman et al. 2008; Flannery 1976; Flannery and Marcus 2005) and in the Mixteca (Balkansky et al. 2009; Kowalewski et al. 2009). By the Middle Formative, large compounds of attached patio groups housed extended families in the Cuicatlán Cañada (Spencer and Redmond 1997). Spencer and Redmond report that the common form of house construction consisted of stone foundations, adobe-brick walls, pole and thatch roofs, and stamped earthen floors (see also Flannery 2002). Marcus (2008) describes the organization of neighborhoods at Monte Albán as modular, with commoner households clustering around higher-status ones in a manner consistent with patronclient relations (see also Blanton 1978). Pérez Rodríguez (2006) combines household excavations with analysis of the extensive lama-bordo terracing system used by the Postclassic Mixtec in communities such as Nicayuju to argue for nonmanagerial, more bottom-up organization of terrace construction, coordinated by siqui corporate kin groups. Her study convincingly links archaeological remains to a system of land tenure, one of the most elusive elements of domestic economies in the archaeological record (other recent studies of domestic agriculture and terracing include Borejsza et al. 2008; López Corral 2000, 2006).

The development of agglutinated houses and neighborhood divisions occurred later in western and northern Mesoamerica, and round houses are common earlier in the sequence (e.g., Darras and Faugère 2007). Beekman (2008) associates the circular patio groups of the Late Formative-Early Classic periods in the Tequila region of Jalisco with corporate power-sharing between lineage groups. Large rectilinear house compounds and neighborhood organization are apparent in Epiclassic sites recently excavated by Pereira and colleagues (2001, 2005, 2007; Migeon and Pereira 2007) in Cerro Barajas, Guanajuato. Residential construction in this region differs significantly from Oaxaca and central Mexico, with many walls constructed entirely of dressed stone slabs and buildings possessing lower stories used for storage. At the Tarascan capital of Tzintzuntzan, roughly three types of residential zones reflecting status were organized into neighborhoods, with 15 such divisions recorded for the city in the late 16th century (Pollard 2003).

This review of house forms suggests that household composition and flexible corporate groups, in a manner consistent with the house society model, were widespread in highland Mesoamerica. Nonetheless, lineage and descent were important organizing principles along with flexibility related to practical—often economic - and political concerns. Lineage and descent may have been relatively more important during the Formative periods in central Mexico and Oaxaca, and through the Classic period in West Mexico. The aristocratic houses with greater wealth and titles known from ethnohistoric documents, such as the tecalli, show how corporate and network political-economic strategies were employed simultaneously, serving as useful models that archaeologists can use to assess diachronic change in such variables. Domestic rituals were fundamental for both strategies as they served equally to foster cohesion between corporate kin groups and to differentiate those with greater access to land, labor, and wealth on the basis of a corresponding differential access to esoteric knowledge and supernatural favor. 


\section{Domestic ritual}

From a functionalist perspective, domestic ritual is the glue that bonds the household activities and corporate identities discussed thus far. Rituals connect people as members of groups that cooperate in economic production and in social and biological reproduction. They foster trust and define affiliation and identity. From a practice-based perspective, ritual is viewed less as mechanically functional or group adaptive and more as recursively generative of social relations (Bell 1992, 1997). Rituals are considered embodied acts whereby individuals come to share understandings of complex interpersonal and ontological concepts. Domestic rituals imbue residential spaces with meaning. They are often formalized and conventional but also allow for subtle variation and resistance to existing hierarchies. They sometimes change dramatically in association with periods of major social upheaval and can serve causal roles in such processes. More detailed recent treatments of archaeological approaches to ritual are provided by Fogelin (2007) and Kyriakidis (2007).

The contributions in two recent volumes on domestic ritual address these issues and provide cases of how beliefs and practices integrated individuals into households and households into communities (Gonlin and Lohse 2007; Plunket 2002). Both volumes assemble a range of case studies from highland Mexico and other regions of Mesoamerica. Household rituals also feature prominently in a volume on ritual economy edited by Wells and Davis-Salazar (2007).

Grove and Gillespie (2002) provide a useful tripartite classification of domestic rituals. They include (1) mortuary rituals, which often involved the interment of household members underneath or in close proximity to the house; (2) general rituals undertaken within house structures and their associated patios; and (3) rituals dedicated to the house, most commonly intended for consecration and termination of structures or construction phases. All three types were clearly practiced throughout the prehispanic sequence, beginning with the earliest sedentary villages.

\section{Mortuary rituals}

In addition to burials, recent work at Tayata indicates that early domestic mortuary rituals also included cremation, which Duncan and colleagues (2008) suggest constituted a special treatment reserved for higher-status families. At Terminal Formative Tetimpa, Uruñuela and Plunket $(2001,2007)$ document the early function of the iconic talud-tablero architectural style as a means of spatially separating the realm of the living, located above the tablero, from the realm of the dead ancestors, who were interred within the talud. They note that houses with higher taluds would have symbolically communicated the lineage depth of particular households, with senior lineages potentially having enjoyed greater prestige and more land holdings. The rapid abandonment of Tetimpa after the eruption of the Popocatepetl volcano left well-preserved altars in the central patios of house groups. These featured effigies of the volcano and sculpted heads likely depicting ancestors. Some also had associated ritual paraphernalia, such as one set consisting of a turtle-shell drum and deer antler (Plunket and Uruñuela 1998, 2002; Uruñuela and Plunket 1998). 
Many of the village rituals at Tetimpa continued within the urban confines of Teotihuacan. The altars of apartment compounds included burials of elder members of households, who were possibly lineage heads for a particular section of the compound, and the very young. This second group reflects the high mortality rates for infants and young children in premodern societies, as well as the common belief among Mesoamerican societies that having been in the world of the living only briefly, they were better suited for communication with ancestors and spirits (Manzanilla 1996, 2002a, 2009; Manzanilla and Serrano 1999). Temples that serviced the neighborhood also existed at Teotihuacan and appear to have integrated corporate groups in a manner similar to the Aztec calpulco (calpolli temple) (Gómez Chávez et al. 2004). As the population of these neighborhoods was similar to Formative villages such as Tetimpa, a Durkheimian interpretation of Teotihuacan might be that the city's inhabitants used preexisting village mechanisms of organization and integration (mechanical solidarity) at the household and neighborhood levels as the foundation for establishing cohesion among a heterogeneous, economically interdependent population (organic solidarity), integrated by state, market, and temple institutions (e.g., Durkheim 1984[1893]; see also Feinman et al. 2008 for Oaxaca). Providing an example of the heterogeneity of Teotihuacan, Spence (2002) documents how the Zapotec, as an ethnic minority in the city, adopted some domestic conventions of their new home while maintaining mortuary rituals from their ancestral home. Drawing on ethnographic Zapotec practices, Spence suggests that deposits of two pottery vessels-one used as a lid over the other-held afterbirths and were ritually deposited in plaza floors of compounds in the Oaxaca barrio.

\section{General rituals}

Among the possible general rituals undertaken within the house and its environs, those involving figurines, burning incense, and bloodletting involve nonperishable artifacts likely to be recovered during excavations. Clay figurines are one of the most abundant and expressive artifact types associated with domestic ritual, though in certain cases they also may have served other purposes such as child socialization through play. Contributions in a recent volume (Halperin et al. 2009) explore the role of figurines in domestic rituals from several highland contexts (see also Lesure 2002, 2005). Marcus (2009) notes that in most cases figurine fragments are encountered as domestic refuse, after having outlived their use life, but certain deposits include ritual "scenes" discovered in situ, which can provide clues to how figurines were manipulated during rituals. For Formative Oaxaca she has highlighted the role of ancestor veneration in figurine making and use as a female-gendered activity (Marcus 1998, 1999). Cyphers Guillén (1993) also argued for the use of figurines in domestic rituals undertaken by women at Chalcatzingo and documented a spatial correlation between figurines and the hearths of houses at the site. Others offer different but possibly complementary interpretations. Blomster (2009) views the increase of figurine types but the decrease in variability within any type during the Early Formative in Oaxaca as an indication of the formalization of 
hierarchical relations and identities, whereas Smith $(2002,2005)$ emphasizes curing rituals over ancestor veneration for Postclassic household rituals involving figurines.

Aromatic tree resins and plants were frequently burned in prehispanic domestic rituals. Ceramic braziers and burners found in archaeological contexts attest to these activities and could provide many valuable insights into ancient domestic ritual practices, yet remarkably few comparative and synthetic studies on the use of ritual censers across culture regions and ceramic phases have been undertaken. This is surprising because censers are one of the more abundant artifact classes in archaeological assemblages, and a broader perspective on their significance is required to advance our understanding of ritual and identity.

An intriguing subset of incense burners is the effigy vessel. These depict a personage-human, animal, or deity-and materialize part of the belief system within which rituals were practiced. It is likely that certain anthropomorphic effigy vessels represent the ancestors of a particular household, although others, especially in highland states, depict powerful social roles within the bureaucracy of a society, including priests, soldiers, and rulers (Cowgill 2002; Flannery and Marcus 2005; González Licón 2003, pp. 256-259; Manzanilla 1996, 2002a; Marcus 1998, 1999, 2008; Marcus and Flannery 1994; Sellen 2002; Smith et al. 2003; Sugiyama 1998). Zoomorphic effigy burners depict a variety of highland fauna, but the prevalence of opossums appears to relate to the deep history of native myths associating the animal with fire (e.g., López Austin 1993; Ramírez 2008). I contend that two prominent deities recognizable from historical periods in central Mexico-the Old God of Fire and Storm God-have roots in effigy vessels of the Formative period (Carballo 2007). Though representations of both deities were manipulated in domestic rituals, differential usages are observable centuries prior to the Classic period, with the Old God associated primarily with households and the Storm God having a more public and political persona. In a related case, Winter (2002) has noted how Zapotec conceptualizations of the Old God and Storm God (Cocijo) were given form on portable effigy vessels, which facilitated their distribution and helped establish widely accepted norms regarding religious belief and ritual practice.

Manzanilla (2002a) lists pouring liquids, scattering seeds and other symbols of fertility, burning incense, and offering goods at altars and domestic temples as the primary domestic ritual practices that maintained solidarity within Teotihuacan's multifamily households (see also Barba et al. 2007). Old God effigy vessels, usually carved from stone, appear to have been central to many of these activities. However, Manzanilla (2009) documents variability in the representation of deities and possibly totemic animals in different sections of apartment compounds such as Oztoyahualco 15B:N6W3 (Fig. 6, bottom). Manzanilla suggests that the Old God would have been the patron deity of certain households in a compound, while different personages served that role for other households.

The second common form of domestic incense burner at Teotihuacan was the composite, theater-style pottery vessels with effigy depictions that usually are interpreted as representing priests, soldiers, and mortuary masks of prominent individuals. Cowgill (1997, p. 142) reasons that a connection between this form of effigy vessel and state religion is suggested not only by virtue of their production in the workshop attached to the Ciudadela but also by the fact that it, like the 
apartment compound, did not survive the collapse of the state. In contrast, the Old God vessel form that originated within the context of village domestic ritual, rather than in association with state religion, both predated and survived Teotihuacan as a polity (e.g., Smith and Hirth 2000, pp. 40-41). Its survival is indicative of the greater pervasiveness of the deity within central Mexican belief.

Bloodletting is a final form of general household practices that Bell (1997, pp. 108-114) would classify as rituals of exchange and communion. Blood would be let and sometimes burned on strips of paper to please, placate, sustain, and communicate with deities and ancestors. The practice was widespread in highland households of the Postclassic and likely was common during earlier periods. However, the perishable implements commonly used for bloodletting, such as maguey and zacate spines, usually do not preserve in the archaeological record. Bloodletters made of obsidian or bone do. Yet, while nearly all households in the highlands had access to obsidian blades, needles or lancets were much more restricted in their circulation. It seems likely that items such as stingray spines and finely retouched obsidian bloodletters were prestige goods not used by everyone (Flannery and Marcus 2005; Parry 1987). Based on deposits from two domestic areas at the Formative site of La Laguna, I argue that knappers in one lower-status household possessed the material and technical competence to make their own fine obsidian bloodletters; thus, the association of such finished implements with elite residences only is more suggestive of use norms in the community (Carballo 2009, pp. 490-491, 494).

Rituals to the house

While mortuary and general rituals in domestic areas served to sacralize residential spaces and to materialize the connections individuals had to them, dedication and termination rituals made houses themselves living and sacred entities. Rituals associated with the construction and use lifecycle of buildings and built spaces operated not only at the scale of monumental public temples but also for humble houses (see contributions in Mock 1998). As a result, houses could be cosmically centered and imbued with symbolic significance, or even a persona. In fact, it is likely that temple rituals of sanctification evolved from practices originally undertaken within residences, which were later altered to serve community, factional, and political ends (Redmond and Spencer 2008).

Feinman and colleagues (2008) document 78 domestic offerings in the construction nuclei of seven residences at El Palmillo, likely associated with rituals of consecration and termination. Most consisted of ceramic vessels and interred animals, which may have been sacrificed for the particular ritual act. They were most commonly found under residential floors. Vessels were either deposited alone or as two-pot offerings placed lip to lip. Single-vessel offerings occasionally contained human or animal remains. Two-pot offerings usually were found without anything recoverable inside them, but occasionally contained obsidian blades. The authors suggest that some may have once held placentas, like Spence (2002) argued for Teotihuacan's Oaxaca barrio. At the community level, Feinman and colleagues argue that similarities in the ritual deposits of proximate domestic areas are 
suggestive of neighborhood organization at El Palmillo. They also note status divisions between neighborhoods, with elites apparently having lived on upper terraces where they conducted more rituals involving a greater diversity of products.

Manzanilla (2003, p. 99) lists common materials used to terminate one structure before beginning another at Teotihuacan, including ceramic vessels, mica, figurines, small incense burners, chipped stone, and slate. Like at El Palmillo, variability in the elaboration of ritual dedications and terminations at Teotihuacan appears to have been connected to larger social dynamics such as suprahousehold organization, status, and politics (Manzanilla 2002a, 2007b).

\section{Household status and elite residences}

Competition between households for status and the variability of residences in hierarchical societies are two themes that have received much attention in highland Mesoamerica. Recent research has focused particularly on discerning household status based on domestic architecture and activities, especially in elaborate residences classifiable as palaces. Edited volumes by Evans and Pillsbury (2004) and Christie and Sarro (2006) include palace studies from many different regions of the Americas, including highland Mesoamerica.

Mesoamerican archaeologists are engaged in healthy debate concerning what exactly constitutes a palace and the social significance of such buildings in different regions and during particular periods. Two major related issues are (1) whether palaces represent a qualitatively different residence type consistent primarily with state-level societies and the institutionalized power that certain officeholders possessed, which permitted them to mobilize large-scale labor for personal ends (Flannery 1998), and (2) whether palaces are better defined by their functions, which are argued to have involved large spaces for semipublic assemblies as a defining attribute (Barber and Joyce 2006). These complex and important issues are most appropriately addressed by working backwards from the well-known palaces of historical periods to contested possibilities from earlier times. It is also prudent to look outside of Mesoamerica for comparative cases that help organize classificatory terms and frameworks, as Sheehy (1996) and Manzanilla (2001) have done.

\section{Postclassic and colonial palaces}

Evans (2004, Table 1) provides a compilation of Aztec palaces classified according to the size and administrative functions of their associated settlements-tecpan calli (lord's place house) for villages, city-states, and imperial capitals. Other classes of elite dwelling spaces include mansions, imperial retreats, pleasure palaces, zoos, game reserves, and horticultural gardens (Evans 1998, 2000, 2001, 2005b, 2006). Only the tecpan possessed the mixed functions of residence and civic-administrative center suited to typical Aztec governance by elite consensus, but the others attest to a richness of courtly life similar to virtually any part of the Old World. The central courtyards in Aztec palaces were their most important feature; they served as the primary loci for semipublic rituals and patron-client political negotiation. All other 
buildings were oriented in relation to them, and inner rooms and sanctuaries possessed varying degrees of exclusivity (Evans 2004).

Most information concerning Aztec palaces is derived from ethnohistoric sources. Complete plans exist for only two village tecpan, and significant excavations have been undertaken at the tecpan from only five city-states. Ethnohistoric accounts of the grandeur of the huetecpan (great lord's place) that once housed emperors in the imperial capitals of Tenochtitlan and Texcoco provide most of our existing knowledge; the structures were largely destroyed by the Spaniards and their foundations now lie under colonial buildings. An example is the palace of Moctezuma Xocoyotzin, which sits beneath modern Mexico City's National Palace.

One of the more extensive excavations of an Aztec palace was conducted by Vaillant in 1935 at the Casas Reales complex in Chiconautla (Vaillant and Sanders 2000). Updated assessments of the complex are provided by Elson (1999), who identifies areas within Casas Reales for public ritual and patron-client interactions, economic activities including textile and obsidian production, and an increase in household access to nonlocal resources such as cotton between the Early and Late Aztec periods. Aztec palaces are also known from excavations at other provincial sites, including Cihuatecpan (Evans 1989, 1991, 1993, 2004), Cuexcomate (Smith 1992), and Yauhtepec (Smith et al. 1999; Vega 1996).

An excellent example of postconquest cultural syncretism is the restored Casa de la Cacica in Teposcolula, a Mixtec palace that was built in the $1560 \mathrm{~s}$. It includes a band of disk-motif friezes near the roof of its principal structure, characteristic of prehispanic palaces. The Mixtec queen would have resided in the main structure, with smaller buildings surrounding an enclosed patio that could have accommodated an assembled crowd for a bullfight or other colonial period gathering (Kiracofe 1995, p. 66). Kirakofe argues that indigenous elites in Teposcolula and other highland communities developed new architectural styles that combined traditional symbols of prestige with novel materials and aesthetics brought by the Spaniards. Recent excavations by Robles García and Spores (2008; Spores and Robles García 2007) in nearby Pueblo Viejo de Teposcolula provide an earlier perspective on the processes of syncretism at a palace that straddles the Postclassic to early colonial periods (see also Evans 2005b for analogous cases from central Mexico).

\section{Defining palaces and palace-centric societies}

When do structures consistent with known indigenous conceptualizations of palaces appear in the archaeological record? Barber and Joyce (2006) draw a heuristic division between elite residences as primarily dwellings and palaces, which they argue must include substantial spaces for semipublic functions that served to construct and reify social relations of power and governance. They part company with scholars working in the Valley of Oaxaca regarding whether the latter dimension of palaces was present in late Monte Albán I and early Monte Albán II (Elson 2007; Marcus and Flannery 1996; Spencer and Redmond 2004a, b, 2005, 2006). Barber and Joyce (2006) contend that for most of Monte Albán's Classic period occupation, Zapotec elite did not live in structures with semipublic audience 
spaces; only during the Late Postclassic did structures exist in Oaxaca that could be classified as palaces. The authors cite cross-cultural examples of very large multifunctional complexes, such as the palaces of Minoan Crete and Potala Palace in Tibet. These cases should be examined more closely to assess their applicability to highland Mesoamerica.

Several Aegean scholars now argue that what have traditionally been called palaces in Minoan society are better classified as ceremonial centers, as they do not appear to have served as residences for kings or chiefs. Driessen and colleagues (2002; Driessen 2003) note that the complexes at Knossos lack compelling evidence for royal burials and domestic food production in a manner consistent with residential functions (see also Galaty and Parkinson 2007). As for the second example, Potala Palace was the residence for the leader of a theocratic state as well as the principal religious structure of that state-containing thousands of shrines and quarters for monks. Early European visitors likened Potala Palace to the Vatican (Waddell 2007). Neither case is particularly appropriate for Mesoamerica, but they offer useful points of comparison. I suggest that Barber and Joyce's (2006, p. 245) more important variable is the exclusionary strategy on the part of elites, which made certain societies or periods in the highlands relatively more or less palacecentric. Nonetheless, palaces also were present in more corporate or inclusive societies such as Teotihuacan. Further, a closer review of the literature from the Valley of Oaxaca makes it clear that large, multifunctional palaces were present by Monte Albán I.

Mesoamerican palaces were often situated near the largest religious structures in a community, but they were not single or contiguous buildings incorporating both sets of functions, as was the case with Potala Palace. The tecpan of Moctezuma Xocoyotzin was just south of Tenochtitlan's Templo Mayor, and while acts of governance could take place at the temple and rituals could take place at the palace, the two were conceptually and physically differentiated. Similar spatial segregation is apparent in Tula's sacred precinct (Mastache and Cobean 2006). At other times or places in highland Mexico, palaces represented more of a focal point for politicoreligious activities, and their architectural elaboration was equal to or exceeded that of major temples. Such a palace orientation was characteristic of groups who were contemporaries of the expanding Triple Alliance in Oaxaca, Puebla, and Tlaxcala, known as the Mixteca-Puebla interaction sphere. These groups had relatively large palaces and modest temples when compared to other Mesoamerican societies. They include the Monte Albán V phase structures from the Valley of Oaxaca at Yagul (Fig. 3), Mitla, El Palmillo, and Lambityeco (for these last two see the recent work of Feinman et al. 2006; Lind and Urcid 2009). This palace-centric interaction sphere extended north from Oaxaca into Tlaxcala, where Pohl $(1998,2003)$ suggests that palatial complexes were used by the networking and intermarrying elites of small kingdoms for ritual feasting that involved ceramics and polychromed altars decorated in the Mixteca-Puebla style. While not large by the standards of more centralized highland states, these palaces represented proportionally more of the civic-ceremonial core of Tlaxcalan kingdoms. They were an important part of an exclusionary political strategy by the elites of an otherwise collective confederation of polities. 
An earlier example of a palace-centric settlement in Tlaxcala is Cacaxtla, where the major construction project in the community was an acropolis-like precinct that served multiple functions, including elite residence, ritual center, and storage facility (Serra Puche and Lazcano 2005, 2008). As such, the "acropolis" of Cacaxtla may have shared some functional similarities to the "palaces" of Minoan Crete, roughly contemporaneous with the more palace-centric, individualizing, and exclusive elite residences in the Valley of Oaxaca during the Monte Albán IIIb-IV phases. The centrality of the palace complex at Cacaxtla, however, is different from the pattern at the three most powerful political capitals in the central Mexican sequence: Tenochtitlan, Tula, and Teotihuacan. Recent excavations at Tula provide an additional instance of palace complexes being located next to major religious structures, yet being physically and functionally differentiated from them (Báez Urincho 2008).

\section{Early palaces}

Most scholars working at Teotihuacan believe that there were palaces in the city predating the central Mexican examples above, but exactly which complexes qualify as palatial and when they may have served as palaces are points of contention. The most likely candidates are the Ciudadela, the Street of the Dead Complex, and the Xalla compound (see Cowgill 1997, 2007, 2008; Evans 2004, 2006; Manzanilla 2001, 2002b, 2006; Manzanilla and López Luján 2001; Sanders and Evans 2006). All three are clearly large enough to have served as palaces; Yagul's Palace of the Six Patios could fit within any of their architectural footprints many times over. They also possess one or more plazas or patios for public or semipublic assembly. Debate regarding if and when any of the three would have served as a palace revolves around other major unknowns for Teotihuacan: its early history, its form of governance, and the mortuary treatment of its leaders. No residences of any kind dating before the Miccaotli phase have been excavated. Cowgill (2008, pp. 105-107) argues that the Ciudadela served as the palace from its construction in that phase until it was replaced by the Street of the Dead Complex, possibly associated with a shift in governance from centralized, autocratic leadership to more collective power sharing. Xalla was once thought to have been a possible early palace, but the recent excavations of Manzanilla, López Luján, and Fash provide a construction date during the Tlamimilolpa phase for the large central plaza, which is arranged as a quincunx with four principal structures ringing a central altar (Manzanilla 2001, 2002b; Manzanilla and López Luján 2001). Dedicatory offerings and other structural remains of a less certain layout predate this configuration, however (Manzanilla 2009). Sculpture friezes depicting jaguars, evidence of prestige-goods production, and the association of each of the central structures with different deities all attest to the great importance of the Xalla compound, which Manzanilla (2006, p. 35) identifies as a palace for possibly two or four coregents.

González Licón (2004, 2009; see also Flannery 2003 [1983]a) takes the more widely accepted position, counter to that of Barber and Joyce (2006), that Monte Albán's North Platform featured the royal palace that served a combination of 
residential and administrative functions. He suggests that royal relatives and intermediate elites lived in the large residences with elaborate subfloor tombs surrounding the ceremonial core of the city (Fig. 3). Following this classification, the palaces at Monte Albán and Teotihuacan are roughly contemporaneous. Yet Monte Albán's deeply buried early constructions are just as poorly known as Teotihuacan's, and it is from excavations elsewhere in the Valley of Oaxaca that current research suggests the initial evolution of palaces associated with Zapotec state formation.

Spencer and Redmond have uncovered a large (approximately $34 \times 25 \mathrm{~m}$ ) residence in the ceremonial core of El Palenque-an early rival settlement to Monte Albán—with an open central patio, dating approximately to the second century BC, during Monte Albán Late I (Redmond and Spencer 2006; Spencer and Redmond 2004b, 2005, 2006). The authors argue that settlement nucleation, increasingly defensible positioning upslope, and secondary state formation were initially successful resistance strategies on the part of the inhabitants of the area, who were confronted with a rapidly urbanizing and militarizing neighbor to the north in Monte Albán. As the structure in the center of El Palenque is larger than any nonroyal Classic period palace at Monte Albán, and semipublic gatherings could have been held in more than half of its associated spaces, there is little doubt that it should be classified as a palace (see Fig. 3 and discussion by Spencer and Redmond 2004b, p. 452).

Elson (2007) identifies two elite residences as palaces at Cerro Tilcajete, the administrative center established in Monte Albán II by the rulers of Monte Albán after subduing the inhabitants of El Palenque and associated sites. She contends that they were built either for administrators from Monte Albán-who were buried at the capital, since no elite burials were uncovered within the structures-or by indigenous elites who had their primary residences elsewhere. Elson (2007, p. 15) draws a useful distinction between residential and administrative palaces, with the former being more common and primarily serving residential functions for intermediate elites and the latter being restricted to political capitals and potentially second-tier administrative centers of large polities (see similar distinctions in Flannery 2003[1983]a; Manzanilla 2001). Since Structure 1 of Cerro Tilcajete's Mound A is similar in size to the historically documented tecpan of Chiconautla reanalyzed by Elson (1999), as well as to colonial period palaces from Oaxaca itself, her classification is compelling. Elson (2007, p. 98) suggests that the change in palaces after Monte Albán III may be related to the collapse of Teotihuacan, which alleviated any external pressures keeping Monte Albán organized as a more corporate polity, and led to the rise of intermediate elites and a greater emphasis on exclusive palace networking.

The problems of house-type definition that researchers confront stem from the fact that variability in the size and semipublic functions of residences is quantitative rather than qualitative (see Sheehy 1996). A recent ethnoarchaeological study by Bowser and Patton (2004) examines how even modest residences in small-scale societies of a couple hundred individuals could serve semipublic, political functions. There is no clear point at which dinner parties or other assemblies of nonkin within houses reach a size that qualifies the structure as palatial rather than simply an elite 
residence. Accordingly, I favor the broader definition of palaces listed above and find Elson's subclassification into residential and administrative palaces useful in distinguishing the scale of semipublic activities that would have taken place at them. The palaces of El Palenque, early Monte Albán, and early Cerro Tilcajete are similar in size and form to the indigenous conceptualization of a palace during the 16th century. More important, the clear antecedents of the palace-centric kingdoms that followed Monte Albán's decentralization are observable in the size and multifunctional arrangement of the Area I palace in El Palenque excavated by Spencer and Redmond (2004b).

\section{Status in other residential contexts}

Palaces, of course, would have housed only a small fraction of any society, and a number of intermediate elite and commoner household arrangements are known from the early colonial period (e.g., Hicks 1986). Archaeological investigations of the full spectrum of household status have continued apace, with the clearest lesson being that multiple lines of evidence are required for assessing variability (e.g., Carballo 2009; Feinman et al. 2006; Grove and Gillespie 1992; Hirth 1993b; Smith et al. 1999). Generally speaking, the relative size and elaboration of houses appear to be most closely correlated with household status in highland Mesoamerica, and the abundance of utilitarian tools appears to be uncorrelated or inversely correlated. The use of particular materials and construction techniques provides one of the most reliable symbols of high-status houses (Blanton 1994; Lohse and Valdez 2004; Lyons 2007). Status differentiation also may be reliably inferred from differences between households in access to desirable goods such as nonlocal resources (e.g., Carballo 2009; Feinman et al. 2006) and disproportional consumption of meat (Haller et al. 2006).

Large horizontal excavations and the analysis of as many material classes as possible are necessary to reliably reconstruct status relations in any single community. Better understandings of variability in household status and its development over time are provided by the recent work of González Licón (2003, 2009) for Monte Albán, and Robertson (2005, 2008, in press) and Manzanilla (2006, 2007b, 2009) for Teotihuacan. Manzanilla's investigations suggest that during the later history of Teotihuacan, intermediate elites living in neighborhood centers such as Teopancazco engaged in exclusionary, networking behaviors that undermined the corporate nature of earlier state power and precipitated state collapse. Changes in status relations are also outlined by Nelson (2004) in an ambitious synthesis of elite architecture for West Mexico, an area he notes could constitute half of Mesoamerica, depending on how one defines the region and its subregions. Nelson highlights tendencies for the spatial segregation and elevation of elite residences in West Mexico and their frequent association with burials or ossuaries. He concludes that clear palaces are not discernible until the Postclassic, exemplified by structures such as Palace B at the Tarascan capital Tzintzuntzan, excavated by Cabrera Castro (1987).

The competition that was prevalent between households and the shifting nature of domestic status differentiation underscore one of the more externally oriented 
dimensions of households: the social units that cooperated in economic pursuits, strategic affiliation, and ritual cohesion jockeyed for position within community and regional social hierarchies. Although all households comprise goal-seeking individuals, they also can be analytically conceptualized as coordinated political actors in competition with other similar units. Collective action on the part of households therefore stimulates and responds to broader-scale change within a larger social universe.

\section{Household transformations and the broader social universe}

One of the major contributions of the rise of household archaeology over the last half century has undoubtedly been the more complete perspective gained by examining the entire socioeconomic spectrum that comprised past societies. Analysis at the household level has brought archaeology more in line with ethnographies of past peoples, allowing for differences in a data set that lacks the cultural details of ethnographic research but which is better suited to studying diachronic, evolutionary change. I focus here on two major topics: (1) the manner in which households became increasingly sedentary and clustered into permanent villages, and (2) how they changed in relation to the political evolution of cities and states. While many other transformative epochs in the history of the highlands merit attention, these two are rightfully classified as "revolutionary" in a Childean sense.

Origins of sedentary village life

As an explanatory framework for cultural change, diffusion has waxed and waned with the influence of broader paradigms, including an overzealous application by early cultural evolutionists and culture historians alike and a reactionary shunning of the concept by processual archaeologists. Somewhere between the extremes of all innovations sharing a single source or being independently derived is a more likely scenario of people developing lifeways in response to their environments, histories, and immediate spheres of interaction. Recent research on the appearance of sedentary agricultural villages in the highlands illustrates a middle ground where independent invention appears to be the best explanation, in some cases, and interaction and selective adoption in others.

Although the origins of Mesoamerican domesticates, especially maize, has long been envisioned as beginning in a particular homeland and spreading elsewhere, the early Mesoamerican village has more often been conceived in terms of the autonomous adoption of agriculturally based sedentism by local, previously more mobile, foraging populations. Household investigations in areas of the highlands that receive lower precipitation or have fewer permanent sources of water, but are still suitable for agriculture, are more suggestive of a two-stage process of sedentism. First, populations in better-watered regions of the highlands began incorporating more domesticates into their diets and adopting increasingly sedentary lifeways - with the natural abundance of some areas, such as the southern Basin of Mexico, likely having permitted at least partial sedentism prior to agriculture 
(e.g., Niederberger 1987; Serra Puche 1988). Next, with population growth, village fissioning led to the colonization of relatively more marginal environments by migrants bringing a Mesoamerican version of the Neolithic package-domesticated plants, pottery, figurines, stone axes, and wattle-and-daub houses. Recent household archaeology in central and northern Tlaxcala (Borejsza et al. 2008; Lesure et al. 2006) and in the Acámbaro Valley of Guanajuato (Darras and Faugère 2007) illustrates this sequence particularly well. It is likely that other regions of the highlands also witnessed migrating agricultural villagers who either mixed with or replaced existing foraging populations, along with other documented cases of foragers who developed agriculture in situ.

With the growth of agricultural villages, households often underwent a corresponding expansion in population. Flannery (2002) provides a comparative overview of the important social transformation from nuclear- to extended-family households in Mesoamerica and the Near East. He notes that larger, extendedfamily households possess advantages over nuclear-family households, including greater economic division of labor and more buffering of risk through group cooperation. In comparing the Mixe and Zapotec, Flannery contends that the former created more isolated farmsteads while the latter practiced more collective laborsuch as irrigation, land clearance, and exploitation of complementary environments - as part of more nucleated settlements. Using Llano Perdido in the Cuicatlan Cañada and Tetimpa in Puebla as examples of extended-family households, Flannery links the proliferation of craft specialization during the Formative with settlement nucleation and the increase in the size and number of elite families.

Household transformations associated with urbanization and political evolution

Settlement nucleation on the much greater scale of cities is a central topic to other household studies (Manzanilla and Chapdelaine 2009). In central Mexico, the work of Plunket and Uruñuela demonstrates the confluence of environmental factors, migration, and social integration in the development of Teotihuacan and Cholula as two of the preeminent cities during the Classic period. The high-intensity eruption of Popocatepetl in the first century AD led to the destruction and abandonment of communities within the zone of eruption deposits immediately to the east, such as Tetimpa, but it also would have created a general sense of chaos that may have stimulated the migration of communities outside of that zone (Plunket and Uruñuela 1998, 2003, 2005, 2006, 2008; see also Siebe 2000). Teotihuacan and Cholula witnessed accelerated urbanization at that time, with populations in the tens of thousands necessitating successful integration through a combination of economic opportunity and political and religious institutions that provided a sense of order, a coercive yet legitimate central authority, and existential purpose-the latter drawing from traditions established in the households and more modest public ritual spaces of the Formative (Plunket and Uruñuela 2002; Plunket et al. 2005; Uruñuela and Plunket 2001, 2007).

Cantona's urbanization into a third major city of the central Mexican Classic period appears to have occurred after these events, but it is related because, according to García Cook (2003), the tightly nucleated city may represent a 
successful strategy of resistance to Teotihuacano political expansionism on the part of formerly independent communities. This expansion eastward, toward the Gulf of Mexico, affected the inhabitants of La Laguna and is associated with the intense conflagration of structures in an elite residential area (Carballo 2009; Carballo and Pluckhahn 2007). Teotihuacan's own fiery end included highly targeted burning and the iconoclastic destruction of sculptures (López Luján et al. 2006a, b; López Luján and Manzanilla 2001; Manzanilla and López Luján 2001).

With no major environmental catastrophes documented from the period of urbanization and state formation in Oaxaca, political factors are of primary importance to the reorganization of households and communities. Spencer and Redmond (1997, p. 602) correlate the shift in domestic architecture from larger compounds to smaller house clusters in the Cuicatlán Cañada with state expansion in the second century BC and a policy imposed by the leaders of Monte Albán to disrupt existing kin networks and more easily administer a newly conquered area (see also Spencer and Redmond 2000, 2001). Together with Elson (2007), they emphasize strategies of resistance to Monte Albán in the nucleation, fortification, and stratification of households in the Tilcajete region (Redmond and Spencer 2006, 2008; Spencer and Redmond 2006).

As for Monte Albán itself, the excavations of González Licón (2003, 2009) at 12 domestic complexes demonstrate various social transformations in households throughout the history of the city. He notes that house construction materials became more elaborate during Monte Albán I, shifting from wattle-and-daub to adobes, but domestic burials were differentiated more in degree than in kind, with respect to both gender and status. By Monte Albán II, indices of social stratification are clearer, with the construction of formal tombs below elite houses and greater meat consumption and shell and jade ornamentation of those individuals who were buried in tombs, which were disproportionately male. Finally, González Licón's suggestion that the city's middle class declined as royals increased in power and the state became more restrictive of nonroyal prestige signaling during Monte Albán III provides a broader perspective on the development of a palace-centric, elite networking system later in the history of the city. This work is paralleled by Manzanilla's (2006, 2007a, 2009) observation that intermediate elites at Teotihuacan undermined the more collective state ideology through faction building and networking alliances later in the city's history, precipitating its political collapse. Both studies demonstrate particularly well how household analyses can contribute to a more developed understanding of large-scale social dynamics.

\section{Conclusion}

During the first pulse of publications on highland Mesoamerican household archaeology (from around 1976 to 1993), the household was firmly established as a fundamental unit of social analysis. Researchers realized that the daily-life issues pertinent to all members of past societies had been eclipsed by a traditional disciplinary emphasis on the public, religious, and political life of past communities, evidenced within the grand plazas and pyramids of Mesoamerican site centers. This 
imbalance began to be rectified through ambitious projects focusing on the origins of settled village life, the variable health, diet, and status of families, and the spatial distribution of craft production and rituals undertaken within households and corporate kin groups (e.g., Flannery 1976; MacEachern et al. 1989; Manzanilla 1986; Santley and Hirth 1993; Wilk and Ashmore 1988).

In the years since, methodological advances have greatly augmented the lines of evidence available for the archaeological reconstruction of household activities. What households do and how they organize themselves have been significantly rethought, and investigations of the aspects of domestic life covered most extensively in the earlier literature continue to expand and mature our understanding of past household dynamics. This thematic overview has covered a broad range of topics, each with its own emphases and associated terminology. By prioritizing what individuals do within domestic groups and how such groups interact with one another, the interconnectivity of these topics becomes apparent and our conceptualizations of households are more grounded in considerations of human action.

Recent literature on household economies encapsulates this point. Studies of multicrafting and intermittent crafting do much more than challenge existing heuristic frameworks that archaeologists have developed for studying craft specialization. They also call attention to the sociality that characterizes households as internally cooperative units and externally interdependent, with household members engaging in interactions that vary between mutualistically cooperative and intensely competitive, depending on the particular context. The notion that households represent self-sufficient units of production is a mischaracterization not grounded in ethnographic realities. As the observation of Watanabe (2007, p. 304) cited earlier makes clear, households are by definition interdependent social units by virtue of their exogamy, which creates potentially vast networks of reciprocal kin and affinal relations with other households. These relationships alone allow for the scalar benefits of specialization, and the intermittent production of multiple types of goods buffers against the risk associated with subsistence economies and the unpredictability of trade and prestige economies. A biological necessity of human groups (incest avoidance) therefore becomes culturally elaborated in myriad ways as people recreate the bonds of affiliation that define who cooperates reciprocally as a group within a setting of similar groups that are in competition with one another. These cultural dynamics are apparent in some of the earliest documented sedentary households in highland Mesoamerica, where domestic assemblages are often indicative of multicrafting and the spatial clustering of houses is suggestive of suprahousehold organization with likely similarities to the corporate kin units known from historical periods.

The manner in which people choose to associate as corporate groups varies widely and is often more flexible and less rule bound than imagined. The house society model appears to have multiple applications in Mesoamerican prehistory, but scholars must restrain themselves from applying it to every possible domestic arrangement and focus more on the valuable emphases within that literature of goalseeking individuals acting in accordance with and against social norms and expectations. Variation in the flexibility of such norms and expectations is culturally and chronologically contingent, and it is where future interesting research questions 
lie. Domestic ritual provides a valuable perspective on this variability, as households venerate ancestors and supernatural entities differently depending on the organization of relatively more lineage-based or collective domestic groups as well as the degree to which social hierarchies are institutionalized. Household rituals in highland Mesoamerica also often involved socially integrative neighborhood temples and altars at which household members congregated to affirm familial and extrafamilial bonds, including forms of economic production and social reproduction.

The larger social universe that households are enmeshed in permeates all dimensions of domestic life, but to different extents. Competition between households for status and resources strongly impacts the manner in which individuals affiliate as groups and in what production activities they cooperate. The remarkable flexibility in composition documented for Teotihuacano apartment compounds (e.g., Spence et al. 2005) is likely correlated with the multiethnic character of the city and its relatively commercialized economy and corporate political structure. I have suggested that these axes of variability may relate directly to the tendencies for Mesoamerican societies to have been more or less pervasively oriented as house societies. More heterogeneous, market-oriented societies with universalizing political ideologies appear likely to have had households of diverse social statuses using affiliation flexibly to maintain physical houses and their heritable possessions. More homogeneous societies with weaker market institutions and more exclusionary political ideologies appear likely to have been organized around noble houses, with less flexibility with regard to descent and lineage.

Status competition between households is archaeologically discernable from the physical houses and domestic assemblages that archaeologists excavate, and multiple lines of reinforcing data on production, consumption, and access are necessary for reconstructing gradations of status in any past community. When households became increasingly nucleated into the first cities and states of the highlands, certain houses became strongly differentiated by their size and semipublic functions, consistent with centralized, bureaucratic decision making by elite consensus - similar to the functions palaces served at the time of conquest. The breakdown of strongly centralized states such as Teotihuacan and Monte Albán appears to coincide with a reconfiguration of certain societies in the former political realms of those polities into more networking, palace-centric kingdoms centered on strong aristocratic houses (González Licón 2003, 2009; Manzanilla 2007b, 2009). These may have resembled the kingdoms from historic periods in the eastern Nahua and Mixtec regions, for which patron-client relations centered on noble houses were the major organizing principle.

Rather than simply envisioning households as reflecting broader social processes, current household archaeology affirms that social change often begins from within domestic spheres of interaction, fostered through more organic institutions of an intermediate scale between households and polities. The diversified foci of current household studies contribute to a more comprehensive understanding of the prehispanic past: one whose houses were peopled by strategically oriented individuals who, through their interdependence and group entanglements, set the course for highland Mesoamerican history. 
Acknowledgments I am grateful to Gary Feinman, Linda Nicholas, and the journal's Editorial Board for the opportunity to write this article and for excellent editorial assistance. Jennifer Carballo, Ken Hirth, and Patricia Plunket graciously read and commented on earlier versions. I have benefited from conversations on different dimensions of households with Luis Barba, Susan Evans, Matthew Restall, Ian Robertson, and David Webster. Bob Cobean and Helen Pollard steered me to valuable citations. I am thankful for the comments I received on how to clarify particular aspects of the article from Linda Manzanilla, Joyce Marcus, Verónica Pérez Rodríguez, Michael Smith, Charles Spencer, and an anonymous reviewer. All inaccuracies and omissions are mine solely. Thanks also to Cathryn Snyder for her assistance in the preparation of Figs. 3, 4, and 6.

Open Access This article is distributed under the terms of the Creative Commons Attribution Noncommercial License which permits any noncommercial use, distribution, and reproduction in any medium, provided the original author(s) and source are credited.

\section{References cited}

Aguirre, Z. (2000). Estudios químicos y paleoetnobotánicos en unidades domésticas arqueológicas del sitio de Tetimpa, Puebla. Unpublished Master's thesis, Department of Anthropology, Universidad de las Américas-Puebla, Cholula.

Aguirre, Z., and Quintana, N. (1998). Análisis químico de cationes de un espacio doméstico arqueológico de la región de Tetimpa, Puebla. In Brambila, R. (ed.), Antropología e historia del occidente de México: XXIV Mesa Redonda, Vol. III, Sociedad Mexicana de Antropología and Universidad Nacional Autónoma de México, Mexico City, pp. 1799-1820.

Alcántara Gallegos, A. (2004). Los barrios de Tenochtitlan: topografía, organización interna y tipología de sus predios. In Escalante Gonzalbo, P. (ed.), Historia de la vida cotidiana en México, Tomo I, Mesoamérica y los ámbitos indígenas de la Nueva España, El Colegio de México, Fondo de Cultura Económica, Mexico City, pp. 167-198.

Aldenderfer, M. (1998). Montane Foragers: Asana and the South-Central Andean Archaic, University of Iowa Press, Iowa City.

Álvarez Díaz, D. (2009). Vida cotidiana en un sector doméstico del Cerro Barajas, Guanajuato: Estudios multidisciplinarios en un asentamiento Epiclásico. Unpublished Licenciatura thesis, Departamento de Antropología, Universidad de las Américas, Puebla.

Báez Urincho, F. (2008). El Edificio 4, un palacio en Tula Grande, el aposento del rey tolteca. Online article published at http://www.famsi.org/reports/07026es/index.html.

Balkansky, A. K., Feinman, G. M., and Nicholas, L. M. (1997). Pottery kilns of ancient Ejutla, Oaxaca, Mexico. Journal of Field Archaeology 24: 139-160.

Balkansky, A. K, Croissier, M. M., and Stearns, S. C. (2009). Multicrafting in prehispanic Oaxaca. In Hirth, K. G. (ed.), Housework: Specialization, Risk, and Domestic Craft Production in Mesoamerica, Archeological Papers No. 19, American Anthropological Association, Washington, DC, pp. 58-74.

Barba, L. (1990). El análisis químico de pisos de unidades habitacionales para determinar sus áreas de actividad. In Sugiura, Y., and Serra Puche, M. C. (eds.), Etnoarqueología: Primer Coloquio BoschGimpera, Instituto de Investigaciones Antropológicas, Universidad Nacional Autónoma de México, Mexico City, pp.177-200.

Barba, L. (1993). Estudios geofísicos y elección del área. In Manzanilla, L. (ed.), Anatomía de un conjunto residencial teotihuacano en Oztoyahualco, Vol. I, Instituto de Investigaciones Antropológicas, Universidad Nacional Autónoma de México, Mexico City, pp. 47-74.

Barba, L. (1994). A methodology for the study of buried archaeological sites. In Scott, D. A., and Meyers, P. (eds.), Archaeometry for Pre-Columbian Sites and Artifacts: Proceedings of a Symposium, Institute of Archaeology, University of California, Los Angeles, pp. 353-366.

Barba, L. (2003). The geophysical study of buried archaeological remains and the preservation of the architectural patrimony of Mexico City. In The CIPA International Archives for Documentation of Cultural Heritage, vol XIX, The ICOMOS and ISPRS Committee for Documentation of Cultural Heritage, Paris, pp. 401-406. 
Barba, L. (2007). Chemical residues in lime-plastered archaeological floors. Geoarchaeology 22: $439-452$.

Barba, L., and Bello, G. (1978). Análisis de fosfato en el piso de una casa habitación actual. Notas Antropológicas 24: 188-193.

Barba, L., and Lazos, L. (2000). Chemical analysis of floors for the identification of activity areas: A review. Antropología y Técnica 6: 59-70.

Barba, L., and Manzanilla, L. (1988). Superficie/excavación: un ensayo de predicción de rasgos arqueológicos en Oztoyahualco, valle de Teotihuacan. Antropológicas 1: 19-46.

Barba, L., and Ortiz, A. (1992). Análisis químico de pisos de ocupación: un caso etnográfico en Tlaxcala, México. Latin American Antiquity 3: 63-82.

Barba, L., and Pereira, G. (2003). Geophysical study of Loma Guadalupe archaeological site in Michoacan, Mexico. Archaeologia Polona 41: 118-122.

Barba, L., Ludlow, B., Manzanilla, L., and Valadez, R. (1987). La vida doméstica en Teotihuacan: un estudio interdisciplinario. Ciencia y Desarrollo 13: 21-32.

Barba, L., García, R., Mejía, E., and Martínez, M. (1999). Determinación de áreas de actividad en una unidad habitacional del Clásico en Azcapotzalco, D.F. Anales de Antropología 33: 69-89.

Barba, L., Ortiz, A., and Manzanilla, L. (2007). Commoner ritual at Teotihuacan, central Mexico: Methodological considerations. In Gonlin, N., and Lohse, J. C. (eds.), Commoner Ritual and Ideology in Ancient Mesoamerica, University Press of Colorado, Boulder, pp. 55-82.

Barber, S. B., and Joyce, A. (2006). When is a house a palace? Elite residences in the Valley of Oaxaca. In Christie, J. J., and Sarro, P. J. (eds.), Palaces and Power in the Americas: From Peru to the Northwest Coast, University of Texas Press, Austin, pp. 211-255.

Beekman, C. S. (2008). Corporate power strategies in the Late Formative to Early Classic Tequila Valleys of central Jalisco. Latin American Antiquity 19: 414-434.

Beekman, C. S. (2010). Recent research in western Mexican archaeology. Journal of Archaeological Research 18: 41-109.

Bell, C. (1992). Ritual Theory, Ritual Practice, Oxford University, Oxford.

Bell, C. (1997). Ritual: Perspectives and Dimensions, Oxford University, Oxford.

Blanton, R. E. (1978). Monte Albán: Settlement Patterns at the Ancient Zapotec Capital, Academic Press, New York.

Blanton, R. E. (1994) Houses and Households: A Comparative Study, Plenum, New York.

Blanton, R. E., and Fargher, L. F. (2008). Collective Action in the Formation of Pre-Modern States, Springer, New York.

Blanton, R. E., Kowalewski, S. A., Feinman, G. M., and Peregrine, P. (1996). A dual-processual theory for the evolution of Mesoamerican civilization. Current Anthropology 37: 1-14.

Blomster, J. P. (2009). Identity, gender, and power: Representational juxtapositions in Early Formative figurines from Oaxaca, Mexico. In Halperin, C. T., Faust, K. A., Taube, R., and Giguet, A. (eds.), Mesoamerican Figurines: Small-Scale Indices of Large-Scale Social Phenomena, University Press of Florida, Gainesville, pp. 119-148.

Bonafil Olivera, A. (2005). Cultura y contexto: el comportamiento de un sitio del Epiclásico en la región de Tula. In Manzanilla, L. (ed.), Reacomodos demográficos del Clásico al Posclásico en el centro de México, Universidad Nacional Autónoma de México, Mexico City, pp. 227-259.

Borejsza, A., Rodríguez López, I., Frederick, C. D., and Bateman, M. D. (2008). Agricultural slope management and soil erosion at La Laguna, Tlaxcala, Mexico. Journal of Archaeological Science 35: $1854-1866$.

Bowser, B. J., and Patton, J. Q. (2004). Domestic spaces as public places: An ethnoarchaeological case study of houses, gender, and politics in the Ecuadorian Amazon. Journal of Archaeological Method and Theory 11: 157-181.

Bruman, H. (1935). Alcohol in Ancient Mexico, University of Utah Press, Salt Lake City.

Brumfiel, E. M. (1998). The multiple identities of Aztec craft specialists. In Costin, C. L., and Wright, R. P. (eds.), Craft and Social Identity, Archeological Papers No. 8, American Anthropological Association, Washington, DC, pp. 145-152.

Brumfiel, E. M. (ed.) (2005). Production and Power at Postclassic Xaltocan, University of Pittsburgh, Pittsburgh, and Instituto Nacional de Antropología e Historia, Mexico.

Brumfiel, E. M. (2006). Cloth, gender, continuity, and change: Fabricating unity in anthropology. American Anthropologist 108: 862-877. 
Brumfiel, E. M., and Earle, T. (1987). Specialization, exchange, and complex societies: An introduction. In Brumfiel, E. M., and Earle, T. (eds), Production, Exchange, and Complex Societies, Cambridge University Press, Cambridge, pp. 1-9.

Cabrera Castro, R. (1987). Tzintzuntzan: décima temporada de excavaciones. In Serra Puche, M. C. (ed.), Homenaje a Román Piñ Chan, Serie Antropológica 79, Instituto de Investigaciones Antropológicas, Universidad Nacional Autónoma de México, Mexico City, pp. 531-565.

Cabrera Castro, R. (1996). Las excavaciones en La Ventilla: un barrio teotihuacano. Revista Mexicana de Estudios Antropológicos XLII: 5-30.

Cabrera Castro, R. (1998). El urbanismo y la arquitectura en La Ventilla: un barrio en la ciudad de Teotihuacan. In Brambila, R. (ed.), Antropología e historia del occidente de México, XXIV Mesa Redonda de la Sociedad Mexicana de Antropología, Mexico, pp. 1523-1547.

Cabrera Castro, R., and Gómez Chávez, S. (2008). La Ventilla: A model for a barrio in the urban structure of Teotihuacan. In Mastache, A. G., Cobean, R. H., García Cook, Á., and Hirth, K. G. (eds.), Urbanism in Mesoamerica, Vol. II, Instituto Nacional de Antropología e Historia, Mexico, and Pennsylvania State University, University Park, pp. 37-84.

Cabrera Cortés, M. O. (2006). Craft production and socio-economic marginality: Living on the periphery of Teotihuacán, México. Online article published at http://www.famsi.org/reports/03090/03090 CabreraCortes01.pdf.

Calnek, E. E. (1972). Settlement pattern and chinampa agriculture at Tenochtitlan. American Antiquity 37: 104-115.

Calnek, E. E. (1974). Conjunto urbana y modelo residencial en Tenochtitlan. In Borah, W. (ed.), Ensayos sobre el desarrollo urbano de México, Secretaría de Educación Pública, Mexico City, pp. 25-54.

Calnek, E. E. (1976). The internal structure of Tenochtitlan. In Wolf, E. R. (ed.), The Valley of Mexico, University of New Mexico Press, Albuquerque, pp. 287-302.

Calnek, E. E. (2003). Tenochtitlan-Tlatelolco: The natural history of a city. In Sanders, W. T., Mastache, A. G., and Cobean, R. H. (eds.), Urbanism in Mesoamerica, Vol. I, Instituto Nacional de Antropología e Historia, Mexico, and Pennsylvania State University, University Park, pp. 149-202.

Carballo, D. M. (2007). Effigy vessels, religious integration, and the origins of the central Mexican pantheon. Ancient Mesoamerica 18: 53-67.

Carballo, D. M. (2009). Household and status in Formative central Mexico: Domestic structures, assemblages, and practices at La Laguna, Tlaxcala. Latin American Antiquity 20: 473-501.

Carballo, D. M., and Pluckhahn, T. (2007). Transportation corridors and political evolution in highland Mesoamerica: Settlement analyses incorporating GIS for northern Tlaxcala, Mexico. Journal of Anthropological Archaeology 26: 607-629.

Carrasco, P. (1964). Family structure of sixteenth-century Tepoztlan. In Manner, R. A. (ed.), Process and Pattern in Culture: Essays in Honor of Julian H. Steward, Aldine, Chicago, pp. 185-210.

Carrasco, P. (1971). Social organization of ancient Mexico. In Ekholm, G., and Bernal, I. (eds.), Handbook of Middle American Indians, Vol. 10, University of Texas Press, Austin, pp. 349-375.

Carrasco, P. (1976). Estratificación social indígena en Morelos durante el siglo XVI. In Carrasco, P., and Broda, J. (eds.), Estratificación social en la Mesoamérica prehispánica, Centro de Investigaciones Superiores, Instituto Nacional de Antropología e Historia, Mexico, pp. 102-117.

Carrera-Hernández, J. J., and Gaskin, S. J. (2008). The Basin of Mexico hydrogeological database (BMHDB): Implementation, queries and interaction with open source software. Environmental Modelling \& Software 23: 1271-1279.

Carsten, J., and Hugh-Jones, S. (eds.) (1995). About the House: Lévi-Strauss and Beyond, Cambridge University Press, Cambridge.

Caso, A. (1956). Los barrios antiguos de Tenochtitlan y Tlatelolco. Memorias de la Academia Mexicana de la Historia 1: 7-62.

Castanzo, R. A. (2009). Ceramics on the side: Pottery making as an augmentation of the household economy in the Valley of Puebla during the Formative period. In Hirth, K. G. (ed.), Housework: Specialization, Risk, and Domestic Craft Production in Mesoamerica, Archeological Papers No. 19, American Anthropological Association, Washington, DC, pp. 133-147.

Castanzo, R. A., and Anderson, J. H. (2004). Formative period lime kilns in Puebla, Mexico. Mexicon 26: $86-90$.

Chance, J. K. (1996). The barrios of colonial Tecali: Patronage, kinship, and territorial relations in a central Mexican community. Ethnology 35: 107-139.

Chance, J. K. (2000). The noble house in colonial Puebla, Mexico: Descent, inheritance, and the Nahua tradition. American Anthropologist 102: 485-502. 
Chance, J. K. (2008). Indigenous ethnicity in colonial central Mexico. In Berdan, F., Chance, J., Sandstrom, A., Stark, B., Taggarty, J., and Umberger, E., Ethnic Identity in Nahua Mesoamerica: The View from Archaeology, Art History, Ethnohistory, and Contemporary Ethnography, University of Utah Press, Salt Lake City, pp. 133-149.

Charlton, T. H., Nichols, D. L., and Otis Charlton, C. (1991). Aztec craft production and specialization: Archaeological evidence from the city-state of Otumba, Mexico. World Archaeology 23: 98-114.

Charlton, T. H., Otis Charlton, C., and Sanders, W. T. (2002). Influencias urbanas dentro de comunidades rurales: Teotihuacan y sus dependencias cercanas 100 a.C. - 650 d.C. In Ruiz Gallut, M. E. (ed.), Ideología y política a través de materiales, imágenes y símbolos: Memoria de la primera mesa redonda de Teotihuacan, Instituto Nacional de Antropología e Historia, Mexico, pp. 487-499.

Christie, J. J., and Sarro, P. J. (eds.) (2006). Palaces and Power in the Americas: From Peru to the Northwest Coast, University of Texas Press, Austin.

Cline, S. L. (1993). The Book of Tributes: Early Sixteenth-Century Nahuatl Censuses from Morelos, Latin American Center Publications, University of California, Los Angeles.

Cobean, R. H., and Mastache, A. G. (eds.) (1999). Tepetitlan: un espacio doméstico rural en al área de Tula, Instituto Nacional de Antropología e Historia, Mexico, and University of Pittsburgh, Pittsburgh.

Costin, C. L. (1991). Craft specialization: Issues in defining, documenting, and explaining the organization of production. In Schiffer, M. B. (ed.), Archaeological Method and Theory, Vol. 3, University of Arizona Press, Tucson, pp. 1-56.

Costin, C. L. (2001). Craft production systems. In Feinman, G. M., and Price, T. D. (eds.), Archaeology at the Millennium: A Sourcebook, Kluwer Academic/Plenum Publishers, New York, pp. 273-327.

Coupland, G., and Banning, E. B. (eds.) (1996). People Who Lived in Big Houses: Archaeological Perspectives on Large Domestic Structures, Prehistory Press, Madison, WI.

Cowgill, G. L. (1997). State and society at Teotihuacan. Annual Review of Anthropology 26: 126-161.

Cowgill, G. L. (2002). Contextos domésticos en Teotihuacan. In Ruiz Gallut, M. E. (ed.), Ideología y politica a través de materiales, imágenes y símbolos: Memoria de la Primera Mesa Redonda de Teotihuacan, Instituto Nacional de Antropología e Historia, Mexico, pp. 61-74.

Cowgill, G.L. (2007). The urban organization of Teotihuacan, Mexico. In Stone, E. L. (ed.), Settlement and Society: Essays Dedicated to Robert McCormick Adams, Cotsen Institute of Archaeology, University of California, Los Angeles, and Oriental Institute, University of Chicago, Chicago, pp. 261-295.

Cowgill, G. L. (2008). Teotihuacan as an urban place. In Mastache, A. G., Cobean, R. H., García Cook, Á., and Hirth, K. G. (eds.), Urbanism in Mesoamerica, Vol. II, Instituto Nacional de Antropología e Historia, Mexico, and Pennsylvania State University, University Park, pp. 85-112.

Craig, N., Aldenderfer, M., and Moyes, H. (2006). Multivariate visualization and analysis of photomapped artifact scatters. Journal of Archaeological Science 33: 1617-1627.

Cyphers Guillén, A. (1993). Women, rituals, and social dynamics at ancient Chalcatzingo. Latin American Antiquity 4: 209-224.

Darras, V. (1999). Tecnologías prehispánicas de la obsidiana: los centros de producción de la región de Zináparo-Prieto, Michoacán, Centre Français d'Études Mexicaines et Centraméricaines, Mexico City.

Darras, V. (2009). Peasant artisans: Household prismatic blade production in the Zacapu region, Michoacán (Milpillas phase 1200 - 1450 AD). In Hirth, K. G. (ed.), Housework: Specialization, Risk, and Domestic Craft Production in Mesoamerica, Archeological Papers No. 19, American Anthropological Association, Washington, DC, pp. 92-114.

Darras, V., and Faugère, B. (2007). Chupícuaro, entre el occidente y el altiplano central: un balance de los conocimientos y las nuevas aportaciones. In Faugère, B. (ed.), Dinámicas culturales entre el occidente, el centro-norte y la cuenca de México, del Preclásico al Epiclásico, Colegio de Michoacán and Centre Français D’Études Mexicaines et Centraméricaines, La Piedad, pp. 51-83.

De León, J. (2009). Rethinking the organization of Aztec salt production: A domestic perspective. In Hirth, K. G. (ed.), Housework: Specialization, Risk, and Domestic Craft Production in Mesoamerica, Archeological Papers No. 19, American Anthropological Association, Washington, DC, pp. 45-57.

De León, J., Hirth, K. G., and Carballo, D. M. (2009). Exploring Formative period obsidian blade trade: Three distribution models. Ancient Mesoamerica 20: 113-128. 
De Lucia, K. (2007). Domestic economies and regional transition: Obsidian and household strategies in Early Postclassic Xaltocan. Paper presented at the 72nd Annual Meeting of the Society for American Archaeology, Austin, TX.

Díaz, C. L. (1981). Chingú y la expansión teotihuacana. In Rattray, E. C., Litvak King, J., and Oyarzabal, C. D. (eds.), Interacción cultural en México central, Universidad Nacional Autónoma de México, Mexico City, pp. 107-112.

Driessen, J. (2003). The court compounds of Minoan Crete: Royal palaces or ceremonial centers? Athena Review 3: 57-61.

Driessen, J., Schoep, I., and Laffineur, R. (eds.) (2002). Monuments of Minos: Rethinking the Minoan Palaces, Aegaeum 23, Université de Liège, Liège.

Duncan, W. N., Balkansky, A. K., Crawford, K., Lapham, H. A., and Meissner, N. J. (2008). Human cremation in Mexico 3,000 years ago. Proceedings of the National Academy of Sciences 105: 5315-5320.

Durkheim, É. (1984[1893]). The Division of Labor in Society, The Free Press, New York.

Elson, C. M. (1999). An Aztec palace at Chiconautla, Mexico. Latin American Antiquity 10: 151-167.

Elson, C. M. (2007). Excavations at Cerro Tilcajete: A Monte Albán II Administrative Center in the Valley of Oaxaca, Museum of Anthropology, University of Michigan, Ann Arbor.

Escalante Gonzalbo, P. (2004). La casa, el cuerpo y las emociones. In Escalante Gonzalbo, P. (ed.), Historia de la vida cotidiana en México, Tomo I, Mesoamérica y los ámbitos indígenas de la Nueva España, El Colegio de México, Fondo de Cultura Económica, Mexico City, pp. 231-259.

Ember, C. (1983). The relative decline in women's contribution to agriculture with intensification. American Anthropologist 2: 285-304.

Evans, S. T. (1989). House and household in the Aztec world: The village of Cihuatecpan. In MacEachern, S., Archer, D. J., and Garvin, R. D. (eds.), Households and Communities: Proceedings of the Twenty-first Annual Conference of the Archaeological Association of the University of Calgary, Archaeological Association, University of Calgary, Calgary, pp. 430-440.

Evans, S. T. (1991). Architecture and authority in an Aztec village: Form and function of the Tecpan. In Harvey, H. R. (ed.), Land and Politics in the Valley of Mexico: A Two-Thousand-Year Perspective, University of New Mexico Press, Albuquerque, pp. 63-92.

Evans, S. T. (1993). Aztec household organization and village administration. In Santley, R. S., and Hirth, K. G. (eds.), Prehispanic Domestic Units in Western Mesoamerica, CRC Press, Boca Raton, FL, pp. $173-189$.

Evans, S. T. (1998). Sexual politics in the Aztec palace: Public, private, and profane. RES: Journal of Anthropology and Aesthetics 33: 165-183.

Evans, S. T. (2000). Aztec royal pleasure parks: Conspicuous consumption and elite status rivalry. Studies in the History of Gardens and Designed Landscapes 20: 206-228.

Evans, S. T. (2001). Aztec noble courts: Men, women, and children of the palace. In Inomata, T., and Houston, S. (eds.), Maya Royal Courts, Westview Press, Boulder, CO, 237-273.

Evans, S. T. (2004). Aztec palaces and other elite residential architecture. In Evans, S. T., and Pillsbury, J. (eds.), Palaces of the Ancient New World, Dumbarton Oaks, Washington, DC, pp. 7-58.

Evans, S. T. (2005a). Men, women, and maguey: The household division of labor among Aztec farmers. In Blanton, R. E. (ed.), Settlement, Subsistence, and Social Complexity: Essays Honoring the Legacy of Jeffrey R. Parsons, Cotsen Institue of Archaeology, University of California, Los Angeles, pp. $198-228$.

Evans, S. T. (2005b). The Aztec palace under Spanish rule: Disk motifs in the Mapa de México de 1550 (Uppsala Map or Mapa de Santa Cruz). In Kepecs, S., and Alexander, R. T. (eds.), The Postclassic to Spanish-Era Transition in Mesoamerica: Archaeological Perspectives, University of New Mexico Press, Albuquerque, pp. 13-33.

Evans, S. T. (2006). Antecedents of the Aztec palace: Palaces and political power in Classic and Postclassic Mexico. In Christie, J. J., and Sarro, P. J. (eds.), Palaces and Power in the Americas: From Peru to the Northwest Coast, University of Texas Press, Austin, pp. 285-310.

Evans, S. T., and Pillsbury, J. (eds.) (2004). Palaces of the Ancient New World, Dumbarton Oaks, Washington, DC.

Feinman, G. M. (1997). Thoughts on new approaches to combining the archaeological and historical records. Journal of Archaeological Method and Theory 4: 367-377.

Feinman, G. M. (1999). Rethinking our assumptions: Economic specialization at the household scale in ancient Ejutla, Oaxaca, Mexico. In Skibo, J. M., and Feinman, G. M. (eds.), Pottery and People: Dynamic Interactions, University of Utah Press, Salt Lake City, pp. 81-98. 
Feinman, G. M., and Nicholas L. M. (1993). Shell ornament production in Ejutla: Implications for highland-coastal interactions in ancient Oaxaca. Ancient Mesoamerica 4: 103-119.

Feinman, G. M., and Nicholas L. M. (1995). Household craft specialization and shell ornament manufacture in Ejutla, Mexico. Expedition 37(2): 14-25.

Feinman, G. M., and Nicholas L. M. (2000). High-intensity household-scale production in ancient Mesoamerica: A perspective from Ejutla, Oaxaca. In Feinman, G. M., and Manzanilla, L. (eds.), Cultural Evolution: Contemporary Viewpoints, Kluwer Academic/Plenum Publishers, New York, pp. 119-142.

Feinman, G. M., and Nicholas, L.M. (2004a). Unraveling the prehispanic highland Mesoamerican economy: Production, exchange, and consumption in the Classic period Valley of Oaxaca. In Feinman, G. M., and Nicholas, L. M. (eds.), Archaeological Perspectives on Political Economies, University of Utah Press, Salt Lake City, pp. 167-188.

Feinman, G. M., and Nicholas, L. M. (2004b). Hilltop Terrace sites of Oaxaca, Mexico: Intensive Surface Survey at Guirún, El Palmillo, and the Mitla Fortress, Fieldiana: Anthropology 37, Field Museum of Natural History, Chicago.

Feinman, G. M., and Nicholas, L. M. (2005). More than alluvial land and water: The late pre-Hispanic emergence of eastern Tlacolula, Oaxaca, Mexico. In Blanton, R. E. (ed.), Settlement, Subsistence, and Social Complexity: Essays Honoring the Legacy of Jeffrey R. Parsons, Cotsen Institute of Archaeology, University of California, Los Angeles, pp. 229-259.

Feinman, G. M., and Nicholas L. M. (2007a). Craft production in Classic period Oaxaca: Implications for Monte Albán's political economy. In Shimada, I. (ed.), Craft Production in Complex Societies: Multicraft and Producer Perspectives, University of Utah Press, Salt Lake City, pp. 97-119.

Feinman, G. M., and Nicholas L. M. (2007b). The socioeconomic organization of the Classic period Zapotec state. In Scarborough, V. L., and Clark, J. E. (eds.), The Political Economy of Ancient Mesoamerica: Transformations during the Formative and Classic Periods, University of New Mexico Press, Albuquerque, pp. 135-147.

Feinman, G. M., Lightfoot, K. G., and Upham, S. (2000). Political hierarchies and organizational strategies in the Puebloan Southwest. American Antiquity 65: 449-470.

Feinman, G. M., Nicholas L. M., and Middleton, W. D. (2001). Domestic life at Classic period hilltop terrace sites: Perspectives from El Palmillo, Oaxaca. Mexicon 23: 42-48.

Feinman, G. M., Nicholas L. M., and Haines, H. R. (2002). Houses on a hill: Classic period domestic life at El Palmillo, Oaxaca, Mexico. Latin American Antiquity 13: 251-277.

Feinman, G. M., Nicholas, L. M., and Haines, H. R. (2006). Socioeconomic inequality and the consumption of chipped stone at El Palmillo, Oaxaca, Mexico. Latin American Antiquity 17: $151-175$.

Feinman, G. M., Nicholas L. M., and Haines, H. R. (2007). Classic period agricultural intensification and domestic life at El Palmillo, Valley of Oaxaca, Mexico. In Thurston, T. L., and Fisher, C. T. (eds.), Seeking a Richer Harvest: The Archaeology of Subsistence Intensification, Innovation, and Change, Springer, New York, pp. 23-61.

Feinman, G. M., Nicholas, L. M., and Maher, E. F. (2008). Domestic offerings at El Palmillo: Implications for community organization. Ancient Mesoamerica 19: 175-194.

Flannery, K. V. (ed.) (1976). The Early Mesoamerican Village, Academic Press, New York.

Flannery, K. V. (1998). The ground plans of archaic states. In Feinman, G. M., and Marcus, J. (eds.), Archaic States, School of American Research Press, Santa Fe, NM, pp. 15-57.

Flannery, K. V. (2002). The origins of the village revisited: From nuclear to extended households. American Antiquity 67: 417-434.

Flannery, K. V. (2003[1983]a). The legacy of the early urban period: An ethnohistoric approach to Monte Albán's temples, residences, and royal tombs. In Flannery, K. V., and Marcus, J. (eds.), The Cloud People: Divergent Evolution of the Zapotec and Mixtec Civilizations, Percheron Press, Clinton Corners, NY, pp. 132-136.

Flannery, K. V. (2003[1983]b). Major Monte Albán V sites: Zaachila, Xoxocotlán, Cuilapan, Yagul, and Abasolo. In Flannery, K. V., and Marcus, J. (eds.), The Cloud People: Divergent Evolution of the Zapotec and Mixtec Civilizations, Percheron Press, Clinton Corners, NY, pp. 290-295.

Flannery, K. V., and Marcus, J. (2005). Excavations at San José Mogote 1: The Household Archaeology, Museum of Anthropology, University of Michigan, Ann Arbor.

Flannery, K. V., and Winter, M. C. (1976). Analyzing household activities. In Flannery, K. V. (ed.), The Early Mesoamerican Village, Academic Press, New York, pp. 34-47.

Fogelin, L. (2007). The archaeology of religious ritual. Annual Review of Anthropology 36: 55-71. 
Fournier García, P. (2007). Los Hñähñü del valle del Mezquital: maguey, pulque y alfarería, Escuela Nacional de Antropología y Historia and Instituto Nacional de Antropología y Historia, Mexico.

Galaty, M. L., and Parkinson, W. A. (2007). Introduction: Mycenaean palaces rethought. In Galaty, M. L., and Parkinson, W. A. (eds.), Rethinking Mycenaean Palaces II, revised and expanded edition, Cotsen Institute of Archaeology, University of California, Los Angeles, pp. 1-20.

García Chávez, R. (1998). Evidencias teotihuacanas en Mesoamérica y su posible significado para la cronología de Teotihuacan. In Brambila, R., and Cabrera, R. (eds.), Los ritmos de cambio en Teotihuacan: reflexiones y discusiones de su cronología, Instituto Nacional de Antropología e Historia, Mexico, pp. 477-502.

García Cook, Á. (1981). The historical importance of Tlaxcala in the cultural development of the Central Highlands. In Sabloff, J. A. (ed.), Supplement to the Handbook of Middle American Indians, Vol. 1, Archaeology, University of Texas Press, Austin, pp. 244-276.

García Cook, Á. (2003). Cantona: la ciudad. In Sanders, W. T., Mastache, A. G., and Cobean, R. H. (eds.), Urbanism in Mesoamerica, Vol. I, Instituto Nacional de Antropología e Historia, Mexico, and Pennsylvania State University, University Park, pp. 312-343.

García Cook, Á., and Merino Carrión, B. L. (1998). Cantona: urbe prehispánica en el altiplano central de México. Latin American Antiqutiy 9: 191-216.

Gillespie, S. D. (2000). Beyond kinship: An introduction. In Joyce, R. A., and Gillespie, S. D. (eds.), Beyond Kinship: Social and Material Reproduction in House Societies, University of Pennsylvania Press, Philadelphia, pp. 1-21.

Gómez Chávez, S. (2000). La Ventilla, un barrio de la antigua ciudad de Teotihuacan. exploraciones y resultados. Unpublished Licenciatura thesis, Departamento de Antropología, Escuela Nacional de Antropología e Historia, Mexico.

Gómez Chávez, S. (2002). Presencia del occidente de México en Teotihuacan: aproximaciones a la política exterior del Estado teotihuacano. In Ruiz Gallut, M. E., and Soto, A. P. (eds.), Ideología y politica a través de materiales, imágenes y símbolos: Memoria de la Primera Mesa Redonda de Teotihuacan, Instituto Nacional de Antropología e Historia, Mexico, pp. 563-626.

Gómez Chávez, S., and Gazzola, J. (2007). Análisis de las relaciones entre Teotihuacán y el occidente de México. In Faugère, B. (ed.), Dinámicas culturales entre el occidente, el centro-norte y la cuenca de México, del Preclásico al Epiclásico, Colegio de Michoacán and Centre Français D’Études Mexicaines et Centraméricaines, La Piedad, pp. 113-137.

Gómez Chávez, S., Gazzola, J., and Núñez Hernández, J. (2004). Nuevas ideas sobre el juego de pelota en Teotihuacan. In Ruiz Gallut, M. E., and Soto, A. P. (eds.), La costa del Golfo en tiempos teotihuacanos: propuestas y perspectivas, Instituto Nacional de Antropología e Historia, Mexico, pp. 165-199.

Gonlin, N., and Lohse, J. C. (eds.) (2007). Commoner Ritual and Ideology in Ancient Mesoamerica, University Press of Colorado, Boulder.

González Licón, E. (2003). Social Inequality at Monte Albán Oaxaca: Household Analysis from Terminal Formative to Early Classic, Ph.D. dissertation, Department of Anthropology, University of Pittsburgh, Pittsburgh.

González Licón, E. (2004). Royal palaces and painted tombs: State and society in the Valley of Oaxaca. In Evans, S. T., and Pillsbury, J. (eds.), Palaces of the Ancient New World, Dumbarton Oaks, Washington, DC, pp. 83-111.

González Licón, E. (2009). Ritual and social stratification at Monte Albán, Oaxaca: Strategies from a household perspective. In Manzanilla, L. R., and Chapdelaine, C. (eds.), Domestic Life in Prehispanic Capitals: A Study of Specialization, Hierarchy, and Ethnicity, Museum of Anthropology, University of Michigan, Ann Arbor, pp. 720.

González-Ruibal, A. (2006). House societies vs. kinship-based societies: An archaeological case from Iron Age Europe. Journal of Anthropological Archaeology 25: 144-173.

Grove, D. C., and Gillespie, S. D. (1992). Archaeological indicators of Formative period elites: A perspective from central Mexico. In Chase, D. Z., and Chase, A. (eds.), Mesoamerican Elites: An Archaeological Assessment, University of Oklahoma Press, Norman, pp. 191-205.

Grove, D. C., and Gillespie, S. D. (2002). Middle Formative domestic ritual at Chalcatzingo, Morelos. In Plunket, P. (ed.), Domestic Ritual in Ancient Mesoamerica, Cotsen Institute of Archaeology, University of California, Los Angeles, pp. 11-19.

Gutiérrez Mendoza, G., Van Rossum, P., and Ortiz Díaz, E. (2000). Least cost path analysis: An estimation of the most efficient communication route between the Valley of Oaxaca and the Gulf Coast plain of Mexico, Río Caxonos Archaeological Project. Antropología y Técnica 6: 11-20. 
Haines, H. R., Feinman, G. M., and Nicholas, L. M. (2004). Household economic specialization and social differentiation: The stone-tool assemblage at El Palmillo, Oaxaca. Ancient Mesoamerica 15: 251-266.

Haller, M. J., Feinman, G. M., and Nicholas, L. M. (2006). Socioeconomic inequality and differential access to faunal resources at El Palmillo, Oaxaca, Mexico. Ancient Mesoamerica 17: 39-55.

Halperin, C. T., Faust, K. A., Taube, R., and Giguet, A. (eds.) (2009). Mesoamerican Figurines: SmallScale Indices of Large-Scale Social Phenomena, University Press of Florida, Gainesville.

Harvey, H. R. (1986). Household and family structure in early colonial Tepetlaoztoc: An analysis of the Códice de Sant María Asunción. Estudios de Cultural Náhuatl 18: 275-294.

Healan, D. M. (ed.) (1989). Tula of the Toltecs: Excavations and Survey, University of Iowa Press, Iowa City.

Healan, D. M. (1993). Urbanism at Tula from the perspective of residential archaeology. In Santley, R. S., and Hirth, K. G. (eds.), Prehispanic Domestic Units in Western Mesoamerica: Studies of the Household, Compound, and Residence, CRC Press, Boca Raton, FL, pp. 105-119.

Healan, D. M. (2009). Household, neighborhood, and urban structure in an "adobe city": Tula, Hidalgo, Mexico. In Manzanilla, L. R., and Chapdelaine, C. (eds.), Domestic Life in Prehispanic Capitals: A Study of Specialization, Hierarchy, and Ethnicity, Museum of Anthropology, University of Michigan, Ann Arbor, pp. 67-88.

Hesse, A., Barba, L., Link, K., and Ortiz, A. (1997). A magnetic and electrical study of archaeological structures at Loma Alta, Michoacan, Mexico. Archaeological Prospection 4: 53-67.

Hicks, F. (1986). Prehispanic background of colonial political and economic organization in central Mexico. In Bricker, V. R., and Spores, R. (eds.), Supplement to the Handbook of Middle American Indians, Vol. 4, Ethnohistory, University of Texas Press, Austin, pp. 35-54.

Hirshman, A. J. (2008). Tarascan ceramic production and implications for ceramic distribution. Ancient Mesoamerica 19: 299-310.

Hirth, K. G. (1975). Estudio de fosfatos en el contexto de arqueología. Vínculos 1: 99-102.

Hirth, K. G. (1993a). The household as an analytical unit: Problems in method and theory. In Santley, R. S., and Hirth, K. G. (eds.), Prehispanic Domestic Units in Western Mesoamerica: Studies of the Household, Compound, and Residence, CRC Press, Boca Raton, FL, pp. 21-36.

Hirth, K. G. (1993b). Identifying rank and socioeconomic status in domestic contexts: An example from central Mexico. In Santley, R. S., and Hirth, K. G. (eds.), Prehispanic Domestic Units in Western Mesoamerica: Studies of the Household, Compound, and Residence, CRC Press, Boca Raton, FL, pp. 121-146.

Hirth, K. G. (1998a). The distributional approach: A new way to identify marketplace exchange in the archaeological record. Current Anthropology 39: 451-476.

Hirth, K. G. (1998b). La identificación de mercados en contextos arqueológicos: una perspectiva sobre el consumo doméstico. In Rattray, E. C. (ed.), Rutas de intercambio en Mesoamérica: III Coloquio Pedro Bosch Gimpera, Universidad Nacional Autónoma de México, Mexico City, pp. 41-54.

Hirth, K. G. (ed.) (2000a). Archaeological Research at Xochicalco, Vol. 1, Ancient Urbanism at Xochicalco: The Evolution and Organization of a Pre-Hispanic Society, University of Utah Press, Salt Lake City.

Hirth, K. G. (ed.) (2000b). Archaeological Research at Xochicalco, Vol. 2, The Xochicalco Mapping Project, University of Utah Press, Salt Lake City.

Hirth, K. G. (2003). Urban structure at Xochicalco, Mexico. In Sanders, W. T., Mastache, A. G., and Cobean, R. H. (eds.), Urbanism in Mesoamerica, Vol. I, Instituto Nacional de Antropología e Historia, Mexico, and Pennsylvania State University, University Park, pp. 257-309.

Hirth, K. G. (ed.) (2006). Obsidian Craft Production in Ancient Central Mexico, University of Utah Press, Salt Lake City.

Hirth, K. G. (2009a). Household, workshop, guild, and barrio: The organization of obsidian craft production in a prehispanic urban center. In Manzanilla, L. R., and Chapdelaine, C. (eds.), Domestic Life in Prehispanic Capitals: A Study of Specialization, Hierarchy, and Ethnicity, Museum of Anthropology, University of Michigan, Ann Arbor, pp. 43-66.

Hirth, K. G. (2009b). Craft production, household diversification, and domestic economy in prehispanic Mesoamerica. In Hirth, K. G. (ed.), Housework: Specialization, Risk, and Domestic Craft Production in Mesoamerica, Archeological Papers No. 19, American Anthropological Association, Washington, DC, pp. 13-32.

Hirth, K. G., and Flenniken, J. J. (2002). Core-blade technology in Mesoamerican prehistory. In Hirth, K. G., and Andrews, B. A. (eds.), Pathways To Prismatic Blades: A Study in Mesoamerican Obsidian 
Core-Blade Technology, Cotsen Institute of Archaeology, University of California, Los Angeles, pp. 121-129.

Hirth, K. G., Serra Puche, M. C., Lazcano Arce, J. C., and De León, J. (2009). Intermittent domestic lapidary production during the Late Formative period at Natavitas, Tlaxcala, Mexico. In Hirth, K. G. (ed.), Housework: Specialization, Risk, and Domestic Craft Production in Mesoamerica, Archeological Papers No. 19, American Anthropological Association, Washington, DC, pp. 157-173.

Hruby, Z. X., and Flad, R. K. (eds.) (2007). Rethinking Craft Specialization in Complex Societies: Archaeological Analyses of the Social Meaning of Production, Archeological Papers No. 17, American Anthropological Association, Washington, DC.

Joyce, R. A., and Gillespie, S. D. (eds.) (2000). Beyond Kinship: Social and Material Reproduction in House Societies, University of Pennsylvania Press, Philadelphia.

Kellogg, S. M. (1986). Kinship and social organization in early colonial Tenochtitlan. In Bricker, V. R., and Spores, R. (eds.), Supplement to the Handbook of Middle American Indians, Vol. 4, Ethnohistory, University of Texas Press, Austin, pp. 103-121.

Kiracofe, J. B. (1995). Architectural fusion and indigenous ideology in early colonial Teposcolula the Casa de la Cacica: A building at the edge of oblivion. Anales del Instituto de Investigaciones Estéticas 66: 45-84.

Kowalewski, S. A., Balkansky, A. K., Stiver Walsh, L. R., Pluckhahn, T. J., Chamblee, J. F., Pérez Rodríguez, V., Heredia Espinoza, V. Y., and Smith, C. A. (2009). Origins of the Nuu: Archaeology in the Mixteca Alta, Mexico, University of Colorado Press, Boulder.

Kurtz, D. V., and Nunley, M. C. (1993). Ideology and work at Teotihuacan: A hermeneutic interpretation. Man 28: 761-778.

Kyriakidis, E. (ed.) (2007). The Archaeology of Ritual, Cotsen Instiute of Archaeology, University of California, Los Angeles.

Lazcano Arce, J. C. (2007). Explotación de recursos en el sitio Natavitas, durante los periodos Formativo y Epiclásico. In Memoria del Primer Coloquio Internacional sobre Cacaxtla a sus XXX Años de Investigación, Centro Regional INAH, Tlaxcala, Mexico.

Lazcano Arce, J. C., Serra Puche, M. C., and Adán Liras, M. (2006). Proyecto etnoarqueológico: la ruta del mezcal. In Brizi Godino, I. (ed.), Etnoarqueología de la prehistoria: más allá de la analogía, Departament d'Arqueologia i Antropologia, Institució Milà i Fontanals, Consejo Superior de Investigaciones Científicas, Madrid, pp. 371-381.

Lesure, R. G. (2002). The goddess diffracted: Thinking about the figurines of early villages. Current Anthropology 43: 587-610.

Lesure, R. G. (2005). Linking theory and evidence in an archaeology of human agency: Iconography, style, and theories of embodiment. Journal of Archaeological Method and Theory 12: 237-255.

Lesure, R. G., Borejsza, A., Carballo, J., Frederick, C., Popper, V., and Wake, T. A. (2006). Chronology, subsistence, and the earliest Formative of central Tlaxcala, Mexico. Latin American Antiquity 17: 474-492.

Lévi-Strauss, C. (1982). The Way of the Masks (trans. S. Modelski), University of Washington Press, Seattle.

Lévi-Strauss, C. (1987). Anthropology and Myth: Lectures 1951-1982 (trans. R. Willis), Blackwell, Oxford.

Levine, M. N. (2007). Linking Household and Polity at Late Postclassic Period Yucu Dzaa (Tututepec), a Mixtec Capital on the Coast of Oaxaca, Mexico, Ph.D. dissertation, Department of Anthropology, University of Colorado, Boulder.

Lewis, B. S. (1996). The role of attached and independent specialization in the development of sociopolitical complexity. Research in Economic Anthropology 17: 357-388.

Lind, M., and Urcid, J. (2009). Lords of Lambityeco: Political Evolution in the Valley of Oaxaca during the Xoo Phase (ca. AD 600-800), University Press of Colorado, Boulder.

Liot, C., Ramírez Urrea, S., Reveles, J., and Melgarejo, C. (2007). Producción, distribución y relaciones interregionales en la cuenca de Sayula de 500 a 1100 d.C. In Faugère, B. (ed.), Dinámicas culturales entre el occidente, el centro-norte y la cuenca de México, del Preclásico al Epiclásico, Colégio de Michoacán and Centre Français D'Études Mexicaines et Centraméricaines, La Piedad, pp. 165-200.

Litvak, J., Barba, L., and Schmidt, P. (1990). A mobile laboratory for surface archaeology. Journal of Field Archaeology 17: 373-378.

Lockhart, J. (1992). The Nahuas after the Conquest: A Social and Cultural History of the Indians of Central Mexico, Sixteenth through Eighteenth Centuries, Stanford University Press, Stanford, CA.

Lohse, J. C., and Valdez, F. (eds.) (2004). Ancient Maya Commoners, University of Texas Press, Austin. 
López Austin, A. (1993). The Myths of the Opossum: Pathways of Mesoamerican Mythology, University of New Mexico Press, Albuquerque.

López Corral, A. (2000). Dos mil años de tradición agrícola: tecnología y organización social durante el Formativo Terminal en Tetimpa, Puebla. Unpublished Licenciatura thesis, Departamento de Antropología, Universidad de las Américas, Puebla.

López Corral, A. (2006). Productividad agrícola y explotación de recursos naturales durante el Formativo en Tetimpa, Puebla. Unpublished masters thesis, Departamento de Antropología, Universidad de las Américas, Puebla.

López Luján, L., Filloy Nadal, L., Fash, B. W., Fash, W. L., and Hernández, P. (2006a). The destruction of images in Teotihuacan: Anthropomorphic sculpture, elite cults, and the end of civilization. RES: Journal of Anthropology and Aesthetics 49/50: 13-39.

López Luján, L., and Manzanilla, L. (2001). Excavaciones en un palacio de Teotihuacan: Proyecto Xalla. Arqueología Mexicana 50: 14-15.

López Luján, L., Filloy Nadal, L., Fash, B. W., Fash, W. L., and Hernández, P. (2006b). El poder de las imágenes: esculturas antropomorfas y cultos de elite en Teotihuacan. In López Luján, L., Carrasco, D., and Cué, L (eds.), Arqueología e historia del centro de México: homenaje a Eduardo Matos Moctezuma, Instituto Nacional de Antropología e Historia, Mexico, pp. 171-201.

Lyons, D. E. (2007). Building power in rural hinterlands: An ethnoarchaeological study of vernacular architecture in Tigray, Ethiopia. Journal of Archaeological Method and Theory 14: 179-207.

MacEachern, S., Archer, D. J., and Garvin, R. D. (eds.) (1989). Households and Communities: Proceedings of the Twenty-first Annual Conference of the Archaeological Association of the University of Calgary, University of Calgary Archaeological Association, Calgary.

Maldonado, B. E. (2008). A tentative model for copper production in the Tarascan state. Ancient Mesoamerica 19: 283-297.

Manzanilla, L. (1985). El sitio de Cuanalan en el marco de las cominidades pre-urbanas del Valle de Teotihuacan. In Monjarás-Ruiz, J., Brambila, R., and Pérez Rocha, E. (eds.), Mesoamérica y el centro de México, Instituto Nacional de Antropología e Historia, Mexico, pp. 133-178.

Manzanilla, L. (ed.) (1986). Unidades habitacionales mesoamericanas y sus áreas de actividad, Universidad Nacional Autónoma de México, Mexico City.

Manzanilla, L. (1996). Corporate groups and domestic activities at Teotihuacan. Latin American Antiquity 7: 228-246.

Manzanilla, L. (2001). Gobierno corporativo en Teotihuacan: una revisión del concepto "palacio" aplicado al la gran urbe prehispánica. Anales de Antropología 35: 157-190.

Manzanilla, L. (2002a). Living with the ancestors and offering to the gods: Domestic ritual at Teotihuacan. In Plunket, P. (ed.), Domestic Ritual in Ancient Mesoamerica, Cotsen Institute of Archaeology, University of California, Los Angeles, pp. 43-52.

Manzanilla, L. (2002b). Organización sociopolítica de Teotihuacan: lo que los materiales arqueológicos nos dicen o nos callan. In Ruiz Gallut, M. E. (ed.), Ideología y política a través de materiales, imágenes y símbolos: Memoria de la Primera Mesa Redonda de Teotihuacan, Instituto Nacional de Antropología e Historia, Mexico, pp. 3-21.

Manzanilla, L. (2003). The abandonment of Teotihuacan. In Inomata, T., and Webb, R. W. (eds.), The Archaeology of Settlement Abandonment in Middle America, University of Utah Press, Salt Lake City, pp. 91-101.

Manzanilla, L. (2006). Estados corporativos arcaicos: organizaciones de excepción en escenarios excluyentes. Cuicuilco 13: 13-45.

Manzanilla, L. (2007a). La unidad doméstica y las unidades de producción: propuesta interdisciplinaria de estudio. La Memoria 2007, El Colegio Nacional, Mexico City, pp. 415-451.

Manzanilla, L. (2007b). Las 'casas' nobles de los barrios de Teotihuacan: estructuras exclusionistas en un entorno corporativo. La Memoria 2007, El Colegio Nacional, Mexico City, pp. 453-470.

Manzanilla, L. (2009). Corporate life in apartment and barrio compounds at Teotihuacan, central Mexico: Craft specialization, hierarchy, and ethnicity. In Manzanilla, L. R., and Chapdelaine, C. (eds.), Domestic Life in Prehispanic Capitals: A Study of Specialization, Hierarchy, and Ethnicity, Museum of Anthropology, University of Michigan, Ann Arbor, pp. 21-42.

Manzanilla, L., and Barba, L. (1990). The study of activities in Classic households: Two case studies from Coba and Teotihuacan. Ancient Mesoamerica 1: 41-49.

Manzanilla, L., and Barba, L. (1994). La arqueología: una visión cientifica del pasado del hombre, Fondo de Cultura Económica, Mexico City. 
Manzanilla, L. R., and Chapdelaine, C. (eds.) (2009). Domestic Life in Prehispanic Capitals: A Study of Specialization, Hierarchy, and Ethnicity, Museum of Anthropology, University of Michigan, Ann Arbor.

Manzanilla, L., and López Luján, L. (2001). Exploraciones en un posible palacio de Teotihuacan: El Proyecto Xalla (2000-2001). Tezontle, Boletín del Centro de Estudios Teotihuacanos 5: 4-6.

Manzanilla, L., and Serrano, C. (eds.) (1999). Prácticas funerarias en la ciudad de los dioses: los enterramientos humanos de la antigua Teotihuacan, Instituto de Investigaciones Antropológicas, Universidad Nacional Autónoma de México, Mexico City.

Marcus, J. (1998). Women's Ritual in Formative Oaxaca: Figurine-Making, Divination, Death and the Ancestors, Memoirs 33, Museum of Anthropology, University of Michigan, Ann Arbor.

Marcus, J. (1999). Men's and women's ritual in Formative Oaxaca. In Grove, D. C., and Joyce, R. A. (eds.), Social Patterns in Pre-Classic Mesoamerica, Dumbarton Oaks, Washington, DC, pp. 67-96.

Marcus, J. (2000). Toward an archaeology of communities. In Canuto, M. A., and Yaeger, J. (eds.), The Archaeology of Communities: A New World Perspective, Routledge, New York, pp. 231-242.

Marcus, J. (2008). Monte Albán, El Colegio de México and Fideicomiso Historia de las Américas, Mexico.

Marcus, J. (2009). Rethinking figurines. In Halperin, C. T., Faust, K. A., Taube, R., and Giguet, A. (eds.), Mesoamerican Figurines: Small-Scale Indices of Large-Scale Social Phenomena, University Press of Florida, Gainesville, pp. 25-50.

Marcus, J., and Flannery, K. V. (1994). Ancient Zapotec ritual and religion: An application of the direct historical approach. In Renfrew, C., and Zubrow, E. B. (eds.), The Ancient Mind: Elements of Cognitive Archaeology, Cambridge University Press, Cambridge, pp. 44-74.

Marcus, J., and Flannery, K. V. (1996). Zapotec Civilization: How Urban Society Evolved in Mexico's Oaxaca Valley, Thames and Hudson, New York.

Martínez Vargas, E., and Jarquín Pacheco, A. M. (1998). Materiales arqueológicos del noroeste de Tlaxcala, Instituto Nacional de Antropología e Historia, Mexico.

Mastache, A. G., and Cobean, R. H. (2003). Urbanism at Tula. In Sanders, W. T., Mastache, A. G., and Cobean, R. H. (eds.), Urbanism in Mesoamerica, Vol. I, Instituto Nacional de Antropología e Historia, Mexico, and Pennsylvania State University, University Park, pp. 217-255.

Mastache, A. G., and Cobean, R. H. (2006). El recinto sagrado de Tula. In López Luján, L., Carrasco, D., and Cué, L (eds.), Arqueología e historia del centro de México: homenaje a Eduardo Matos Moctezuma, Instituto Nacional de Antropología e Historia, Mexico, pp. 203-216.

Mastache, A.G., Cobean, R. H., and Healan, D. M. (eds.) (2002). Ancient Tollan: Tula and the Toltec Heartland, University Press of Colorado, Boulder.

McCaa, R. (2003). The Nahua calli of ancient Mexico: Household, family, and gender. Continuity and Change 18: 23-28.

Mejía Pérez Campos, E., and Barba, L. (1991). Estudio de áreas de actividad por medios químicos en Ranas y Toluquilla, Querétaro. In Crespo, A. M., and Brambila, R. (eds.), Querétaro prehispánico, Instituto Nacional de Antropología e Historia, Mexico, pp. 225-252.

Migeon, G., and Pereira, G. (2007). La secuencia ocupacional y cerámica del Cerro Barajas, Guanajuato y sus relaciones con el centro, el occidente y el norte de México. In Faugère, B. (ed.), Dinámicas culturales entre el occidente, el centro-norte y la cuenca de México, del Preclásico al Epiclásico, Colegio de Michoacán and Centre Français D’Études Mexicaines et Centraméricaines, La Piedad, pp. 201-230.

Millon, R. (1981). Teotihuacan: City, state, and civilization. In Sabloff, J. A. (ed.), Supplement to the Handbook of Middle American Indians, Vol. 1, Archaeology, University of Texas Press, Austin, pp. $198-243$.

Millon, R. (1992). Teotihuacan studies: From 1950 to 1990 and beyond. In Berlo, J. C. (ed.), Art, Ideology, and the City of Teotihuacan, Dumbarton Oaks, Washington, DC, pp. 339-419.

Mock, S. B. (ed.) (1998). The Sowing and the Dawning: Termination, Dedication, and Transformation in the Archaeological and Ethnographic Record of Mesoamerica, University of New Mexico Press, Albuquerque.

Monaghan, J. (1996). The Mesoamerican community as a "great house." Ethnology 35: 181-194.

Mulhare, E. M. (1996). Barrio matters: Toward an ethnology of Mesoamerican customary social units. Ethnology 35: 93-106.

Múnera Bermúdez, L. C. (1985). Un taller de cerámica ritual en la Ciudadela, Teotihuacan. Unpublished Licenciatura thesis, Departamento de Antropología, Escuela Nacional de Antropología e Historia, Mexico. 
Nelson, B. A. (2004). Elite residences in west Mexico. In Evans, S. T., and Pillsbury, J. (eds.), Palaces of the Ancient New World, Dumbarton Oaks, Washington, DC, pp. 59-81.

Netting, R. M. (1982). Some home truths on household size and wealth. American Behavioral Scientist 25: $641-662$.

Netting, R. M., Wilk, R. R., and Arnould, E. J. (eds.) (1984). Households: Comparative and Historical Studies of the Domestic Group, University of California Press, Berkeley.

Nichols, D. L., McLaughlin, M. J., and Benton, M. (2000). Production intensification and regional specialization: maguey fibers and textiles in the Aztec city-state of Otumba. Ancient Mesoamerica 11: 267-291.

Niederberger, C. (1987). Paleopaysages et archaeologie pre-urbaine du bassin de México (Mexique), Vols. 1 and 2, Centre d'Etudes Mésoaméricaines et Centramericaines, Mexico.

Nutini, H. G. (1968). San Bernardino Contla: Marriage and Family Structure in a Tlaxcalan Municipio, University of Pittsburgh Press, Pittsburgh.

Nutini, H. G. (1996). Mesoamerican community organization: Preliminary remarks. Ethnology 35: 81-92.

Offner, J. A. (1984). Household organization in the Texcocan heartland: The evidence in the Codex Vergara. In Harvey, H. R., and Prem, H. J. (eds.), Explorations in Ethnohistory: Indians of Central Mexico in the Sixteenth Century, University of New Mexico Press, Albuquerque, pp. 127-146.

Ortiz Butrón, A., and Barba, L. (1993). La química en el estudio de áreas de actividad. In Manzanilla, L. (ed.), Anatomía de un conjunto residencial teotihuacano en Oztoyahualco, Vol. II, Instituto de Investigaciones Antropológicas, Universidad Nacional Autónoma de México, Mexico City, pp. 617-660.

Paredes Gudiño, B. L. (1990). Unidades habitacionales en Tula, Hidalgo, Colección Científica No. 210, Instituto Nacional de Antropología e Historia, Mexico.

Paredes Gudiño, B. (2005). Análisis de flujos migratorios y comparación multiétnica de la población de Tula, Hgo. In Manzanilla, L. (ed.), Reacomodos demográficos del Clásico al Posclásico en el centro de México, Instituto de Investigaciones Antropológicas, Universidad Nacional Autónoma de México, Mexico City, pp. 203-225.

Parry, W. J. (1987). Chipped Stone Tools in Formative Oaxaca, Mexico: Their Procurement, Production and Use, Memoirs No. 20, Museum of Anthropology, University of Michigan, Ann Arbor.

Parsons, J. R. (2006) The aquatic component of Aztec subsistence: Hunters, fishers, and collectors in an urbanized society. In López Luján, L., Carrasco, D., and Cué, L. (eds.), Arqueología e historia del centro de México: homenaje a Eduardo Matos Moctezuma, Instituto Nacional de Antropología e Historia, Mexico, pp. 241-256.

Parsons, J. R., and Parsons, M. (1990). Maguey Utilization in Highland Central Mexico: An Archaeological Ethnography, Museum of Anthropology, University of Michigan, Ann Arbor.

Peacock, D. P. S. (1982). Pottery in the Roman World: An Ethnoarchaeological Approach, Longman, London.

Pereira, G., Migeon, G., and Michelet, D. (2001). Archéologie du massif du Barajas: premières données sur l'évolution des sociétés préhispaniques du sud-ouest du Guanajuato, Mexique. Journal de la Société des Américanistes 87: 265-281.

Pereira, G., Migeon, G., and Michelet, D. (2005). Transformaciones demográficas y culturales en el centro-norte de México en vísperas del Posclásico: los sitios del Cerro Barajas (suroeste de Guanajuato). In Manzanilla, L. (ed.), Reacomodos demográficos del Clásico al Posclásico en el centro de México, Instituto de Investigaciones Antropológicas, Universidad Nacional Autónoma de México, Mexico City, pp. 123-136.

Pereira, G., Michelet, D., and Migeon, G. (2007). Cerro Barajas, Guanajuato. Arqueología Mexicana XV(87): 77-82.

Pérez Negrete, M. (2004). El Cerro de la Estrella: unidades políticas de la cuenca de México, periféricas a Teotihuacan y la transición al Epiclásico. Arqueología 34: 38-61.

Pérez Pérez, J. (2008). Terrace agriculture in Cerro San Lucas, Teotihuacan Valley. Online article published at http://www.famsi.org/reports/05028/.

Pérez Rodríguez, V. (2006). States and households: The social organization of terrace agriculture in Postclassic Mixteca Alta, Oaxaca, Mexico. Latin American Antiquity 17: 3-22.

Perkins, S. M. (2005). Corporate community or corporate houses? Land and society in a colonial Mesoamerican community. Culture and Agriculture 27: 16-34.

Pires-Ferreira, J. W. (1975). Formative Mesoamerican Exchange Networks with Special Reference to the Valley of Oaxaca, Memoirs No. 7, Museum of Anthropology, University of Michigan, Ann Arbor. 
Plunket, P. (ed.) (2002). Domestic Ritual in Ancient Mesoamerica, Cotsen Institute of Archaeology, University of California, Los Angeles.

Plunket, P., and Uruñuela, G. (1998). Preclassic household patterns preserved under volcanic ash at Tetimpa, Puebla. Latin American Antiquity 9: 287-309.

Plunket, P., and Uruñuela, G. (2002). Shrines, ancestors, and the volcanic landscape at Tetimpa, Puebla. In Plunket, P. (ed.), Domestic Ritual in Ancient Mesoamerica, Cotsen Institute of Archaeology, University of California, Los Angeles, pp. 31-42.

Plunket, P., and Uruñuela, G. (2003). From episodic to permanent abandonment: Responses to volcanic hazards at Tetimpa, Puebla, Mexico. In Inomata, T., and Webb, R. W. (eds.), The Archaeology of Settlement Abandonment in Middle America, University of Utah Press, Salt Lake City, pp. 13-27.

Plunket, P., and Uruñuela, G. (2005). Recent research in Puebla prehistory. Journal of Archaeological Research 13: 89-127.

Plunket, P., and Uruñuela, G. (2006). Social and cultural consequences of a Late Holocene eruption of Popocatépetl in central Mexico. Quaternary International 151: 19-28.

Plunket, P., and Uruñuela, G. (2008). Mountain of sustenance, mountain of destruction: The prehispanic experience with Popocatépetl volcano. Journal of Volcanology and Geothermal Research 170: 111-120.

Plunket, P., Uruñuela, G., Glascock, M., and Neff, H. (2005). A rural perspective on Mesoamerican integration during the Late and Terminal Formative. In Powis, T. G. (ed.), New Perspectives on Formative Mesoamerican Cultures, BAR International Series No. 1377, British Archaeological Reports, Oxford, pp. 183-194.

Pohl, J. M. (1998). Themes of drunkenness, violence, and factionalism in Tlaxcalan altar paintings. RES: Journal of Anthropology and Aesthetics 33: 185-207.

Pohl, J. M. (2003). Royal marriage and confederacy building among the eastern Nahuas, Mixtecs, and Zapotecs. In Smith, M. E., and Berdan, F. F. (eds.), The Postclassic Mesoamerican World, University of Utah Press, Salt Lake City, pp. 243-248.

Pollard, H. P. (1997). Recent research in West Mexican archaeology. Journal of Archaeological Research 5: $345-384$.

Pollard, H. P. (2003). Central places and cities in the core of the Tarascan state. In Sanders, W. T., Mastache, A. G., and Cobean, R. H. (eds.), Urbanism in Mesoamerica, Vol. I, Instituto Nacional de Antropología e Historia, Mexico, and Pennsylvania State University, University Park, pp. 345-390.

Price, T. D., Manzanilla, L., and Middleton, W. D. (2000). Immigration and the ancient city of Teotihuacan in Mexico: A study using strontium isotope ratios in human bone and teeth. Journal of Archaeological Science 27: 903-913.

Ramírez, E. (2008). Origen del fuego. Arqueología Mexicana XV(90): 16-17.

Rapoport, A. (1969). House Form and Culture, Prentice-Hall, Englewood Cliffs, NJ.

Rattray, E. C. (1993). The Oaxaca Barrio at Teotihuacan, Universidad de las Américas - Puebla, Cholula.

Rattray, E. C. (2001). Teotihuacan: Ceramics, Chronology and Cultural Trends, University of Pittsburgh, Pittsburgh, and Instituto Nacional de Antropología e Historia, Mexico.

Rattray, E. C., (2004). Etnicidad en el Barrio de los Comerciantes, Teotihuacan, y sus relaciones con Veracruz. In Ruiz Gallut, M. E., and Pascual Soto, A. (eds.), La costa del Golfo en tiempos teotihuacanos: propuestas y perspectivas, Instituto Nacional de Antropología e Historia, Mexico, pp. 493-512.

Redmond, E. M., and Spencer, C. S. (2006). From raiding to conquest: Warfare strategies and early state development in Oaxaca, Mexico. In Arkush, E. N., and Allen, M. W. (eds.), The Archaeology of Warfare: Prehistories of Raiding and Conquest, University Press of Florida, Gainesville, pp. 336-393.

Redmond, E. M., and Spencer, C. S. (2008). Rituals of sanctification and the development of standardized temples in Oaxaca, Mexico. Cambridge Archaeological Journal 18: 239-266.

Restall, M., Sousa, L., and Terraciano, K. (eds.) (2005). Mesoamerican Voices: Native-Language Writings from Colonial Mexico, Oaxaca, Yucatan and Guatemala, Cambridge University Press, Cambridge.

Robertson, I. G. (1999). Spatial and multivariate analysis, random sampling error, and analytical noise: Empirical Bayesian methods at Teotihuacan, Mexico. American Antiquity 64: 137-152.

Robertson, I. G. (2005). Patrones diacrónicos en la constitución de los vecindarios teotihuacanos. In Ruiz Gallut, M. E., and Torres Peralta, J. (eds.), Arquitectura y urbanismo: pasado y presente de los espacios en Teotihuacan, Instituto Nacional de Antropología e Historia, Mexico, pp. 277-294.

Robertson, I. G. (2008). 'Insubstantial' residential structures at Teotihuacán, Mexico. Online article published at http://www.famsi.org/reports/06103/. 
Robertson, I. G. (in press). Mapping the Social Landscape of an Early City: Teotihuacan, Mexico, University of Arizona Press, Tucson.

Robichaux, D. L. (1997). Residence rules and ultimogeniture in Tlaxcala and Mesoamerica. Ethnology 36: $149-171$.

Robin, C. (2003). New directions in Classic Maya household archaeology. Journal of Archaeological Research 11: 307-356.

Robles García, N., and Spores, R. (2008). Teposcolula, Oaxaca. Arqueología Mexicana XV(90): 42-43.

Sanders, W. T. (1956). The central Mexican symbiotic region: A study in prehistoric settlement patterns. In Willey, G. R. (ed.), Prehistoric Settlement Patterns in the New World, Viking Fund Publications in Anthropology, New York, pp. 115-127.

Sanders, W. T., and Evans, S. T. (2006). Rulership and palaces at Teotihuacan. In Christie, J. J., and Sarro, P. J. (eds.), Palaces and Power in the Americas: From Peru to the Northwest Coast, University of Texas Press, Austin, pp. 256-284.

Santley, R. S. (1989). Residential site structure in the Basin of Mexico during the Formative and Classic periods. In MacEachern, S., Archer, D. J. W., and Garvin, R. D. (eds.), Households and Communities: Proceedings of the Twenty-first Annual Conference of the Archaeological Association of the University of Calgary, University of Calgary Archaeological Association, Calgary, pp. 398-406.

Santley, R. S., (1993). Late Formative period society at Loma Torremote: A consideration of the redistribution vs. the great provider models as a basis for the emergence of complexity in the Basin of Mexico. In Santley, R. S., and Hirth, K. G. (eds.), Prehispanic Domestic Units in Western Mesoamerica: Studies of the Household, Compound, and Residence, CRC Press, Boca Raton, FL, pp. 67-86.

Santley, R. S., and Hirth, K. G. (eds.) (1993). Prehispanic Domestic Units in Western Mesoamerica: Studies of the Household, Compound, and Residence, CRC Press, Boca Raton, FL.

Schortman, E. M., and Urban, P. A. (2004). Modeling the roles of craft production in ancient political economies. Journal of Archaeological Research 12: 185-226.

Schroeder, S., Wood, S., and Haskett, R. (eds.) (1996). Indian Women of Early Mexico, University of Oklahoma Press, Norman.

Sellen, A. T. (2002). Storm-god impersonators from ancient Oaxaca. Ancient Mesoamerica 13: 3-19.

Serra Puche, M. C. (1986). Unidades habitacionales del Formativo en la cuenca de México. In Manzanilla, L. (ed.), Unidades habitacionales mesoamericanas y sus áreas de actividad, Universidad Nacional Autónoma de México, Mexico City, pp. 161-192.

Serra Puche, M. C. (1988). Los recursos lacustres de la cuenca de México durante el Formativo, Universidad Nacional Autónoma de México, Mexico City.

Serra Puche, M. C., and Lazcano Arce, J. C. (2005). El Epiclásico en el valle Puebla-Tlaxcala y los sitios de Cacaxtla-Xochitécatl-Natavitas. In Manzanilla, L. (ed)., Reacomodos demográficos del Clásico al Posclásico en el centro de México, Instituto de Investigaciones Antropológicas, Universidad Nacional Autónoma de México, Mexico City, pp. 287-301.

Serra Puche, M. C., and Lazcano Arce, J. C. (2006). Producción y especialización en CacaxtlaXochitécatl-Natavitas durante los periodos Formativo y Epiclásico. In Fournier, P., Wiesheu, W., and Charlton, T. H. (eds.), Arqueología y complejidad social, special issue of Cuicuilco 13(36): 69-86.

Serra Puche, M. C., and Lazcano Arce, J. C. (2008). Urban configuration at Cacaxtla-Xochitecatl. In Mastache, A. G., Cobean, R. H., García Cook, Á., and Hirth, K. G. (eds.), Urbanism in Mesoamerica, Vol. II, Instituto Nacional de Antropología e Historia, Mexico, and Pennsylvania State University, University Park, pp. 133-164.

Serra Puche, M. C., Lazcano Arce, J. C., and Hernández Hernández, J. S. (2000). Hornos para la producción de mezcal en un sitio del Formativo de Tlaxcala? Arqueología 24: 149-157.

Serra Puche, M. C., Lazcano Arce, J. C., and de la Torre Mendoza, M. (2004). Explotación prehispánica de recursos en el sur del valle de Tlaxcala: una perspectiva de género. In Alberti Manzanares, P. (ed.), Género, ritual y desarrollo sostenido en comunidades rurales de Tlaxcala, Plaza y Valdés, Mexico, pp. 199-226.

Sheehy, J. J. (1996). Ethnographic analogy and the royal household in 8th century Copan. In Mastache, A. G., Parsons, J., Santley, R., and Serra Puche, M. C. (eds.), Arqueología mesoamericana: homenaje a William T. Sanders Vol. 2, Instituto Nacional de Antropología e Historia, Mexico, pp. 253-276.

Shimada, I. (ed.) (2007). Craft Production in Complex Societies: Multicraft and Producer Perspectives, University of Utah Press, Salt Lake City. 
Siebe, C. (2000). Age and archaeological implications of Xitle volcano, southwestern basin of Mexico City. Journal of Volcanology and Geothermal Research 104: 45-64.

Smith, M. E. (1987). Household possessions and wealth in agrarian states: Implications for archaeology. Journal of Anthropological Archaeology 6: 297-335.

Smith, M. E. (1992). Archaeological Research at Aztec Period Rural Sites in Morelos, Mexico, Vol. 1, Memoirs No. 4, Latin American Archaeology, University of Pittsburgh, Pittsburgh.

Smith, M. E. (1993). Houses and the settlement hierarchy in Late Postclassic Morelos: A comparison of archaeology and ethnohistory. In Santley, R. S., and Hirth, K. G. (eds.), Prehispanic Domestic Units in Western Mesoamerica: Studies of the Household, Compound, and Residence, CRC Press, Boca Raton, FL, pp. 191-206.

Smith, M. E. (2002). Domestic ritual at Aztec provincial sites in Morelos. In Plunket, P. (ed.), Domestic Ritual in Ancient Mesoamerica, Cotsen Institute of Archaeology, University of California, Los Angeles, pp. 93-114.

Smith, M. E. (2004a). The archaeology of ancient state economies. Annual Review of Anthropology 33: $73-102$.

Smith, M. E. (2004b). Los hogares de Morelos en el sistema mundial mesoamericano postclásico. Relaciones (El Colegio de Michoacán) 25(99): 79-113.

Smith, M. E. (2005). Aztec-style ceramic figurines from Yautepec, Morelos. Mexicon 27: 45-55.

Smith, M. E. (2008). Aztec City-State Capitals, University Press of Florida, Gainesville.

Smith, M. E., and Heath-Smith, C. (1994). Rural economy in Late Postclassic Morelos: An archaeological study. In Hodge, M. G., and Smith, M. E. (eds.), Economies and Polities in the Aztec Realm, Institute for Mesoamerican Studies, Albany, NY, pp. 349-376.

Smith, M. E., and Lind, M. D. (2005). Xoo-phase ceramics from Oaxaca found at Calixtlahuaca in central Mexico. Ancient Mesoamerica 16: 169-177.

Smith, M. E., Heath-Smith C., and Montiel L. (1999). Excavations of Aztec urban houses at Yautepec, Morelos, Mexico. Latin American Antiquity 10: 133-150.

Smith, M. E., Wharton, J. B., and Olson, J. M. (2003). Aztec feasts, rituals, and markets: Political uses of ceramic vessels in a commercial economy. In Bray, T. L. (ed.), The Archaeology and Politics of Food and Feasting in Early States and Empires, Springer, New York, pp. 235-268.

Smith, V., and Hirth, K. G. (2000). A catalog of carved monuments and a guide to the visual characteristics of Xochicalco's art style. In Hirth, K. G. (ed.), Archaeological Research at Xochicalco, Vol. 2, The Xochicalco Mapping Project, University of Utah Press, Salt Lake City, pp. 17-56.

Spence, M. W. (1974). Residential practices and the distribution of skeletal traits in Teotihuacan, Mexico. Man 9: 262-273.

Spence, M. W. (2002). Domestic ritual in Tlailotlacan, Teotihuacan. In Plunket, P. (ed.), Domestic Ritual in Ancient Mesoamerica, Cotsen Institute of Archaeology, University of California, Los Angeles, pp. 53-66.

Spence, M. W., White, C. D., Longstaffe, F. J., Rattray, E. C., and Law, K. R. (2004). Un análisis de las proporciones de los isótopos del oxígeno en los entierros del Barrio de los Comerciantes. In Ruiz Gallut, M. E., and Pascual Soto, A. (eds.), La costa del Golfo en tiempos teotihuacanos: propuestas y perspectivas, Instituto Nacional de Antropología e Historia, Mexico, pp. 469-492.

Spence, M. W., White, C. D., Rattray, E. C., and Longstaffe, F. J. (2005). Past lives in different places: The origins and relationships of Teotihuacan's foreign residents. In Blanton, R. E. (ed.), Settlement, Subsistence, and Social Complexity: Essays Honoring the Legacy of Jeffrey R. Parsons, Cotsen Institute of Archaeology, University of California, Los Angeles, pp. 155-197.

Spencer, C. S., and Redmond, E. M. (1997). Archaeology of the Cañada de Cuicatlán, Oaxaca, Anthropological Papers No. 80, American Museum of Natural History, New York.

Spencer, C. S., and Redmond, E. M. (2000). Lightning and jaguars: Iconography, ideology, and politics in Formative Cuicatlán, Oaxaca. In Feinman, G. M., and Manzanilla, L. (eds.), Cultural Evolution: Contemporary Viewpoints, Kluwer Academic/Plenum Publishers, New York, pp. 145-175.

Spencer, C. S., and Redmond, E. M. (2001). The chronology of conquest: Implications of new radiocarbon analyses from the Cañada de Cuicatlán, Oaxaca. Latin American Antiquity 12: 182-202.

Spencer, C. S., and Redmond, E. M. (2004a). Primary state formation in Mesoamerica. Annual Review of Anthropology 33: 173-199.

Spencer, C. S., and Redmond, E. M. (2004b). A late Monte Albán I phase (300-100 B.C.) palace in the Valley of Oaxaca. Latin American Antiquity 15: 441-455. 
Spencer, C. S., and Redmond, E. M. (2005). Institutional development in Late Formative Oaxaca: The view from San Martín Tilcajete. In Powis, T. G. (ed.), New Perspectives on Formative Mesoamerican Cultures, BAR International Series No. 1377, British Archaeological Reports, Oxford, pp. 171-182.

Spencer, C. S., and Redmond, E. M. (2006). Resistance strategies and early state formation in Oaxaca, Mexico. In Elson, C. M., and Covey, R. A. (eds.), Intermediate Elites in Pre-Columbian States and Empires, University of Arizona Press, Tucson, pp. 21-43.

Spores, R. (1984). The Mixtecs in Ancient and Colonial Times, University of Oklahoma Press, Norman. Spores, R., and Flannery, K. V. (2003[1983]). Sixteenth-century kinship and social organization. In Flannery, K. V., and Marcus, J. (eds.), The Cloud People: Divergent Evolution of the Zapotec and Mixtec Civilizations, Percheron Press, Clinton Corners, NY, pp. 339-342.

Spores, R., and Robles García, N. (2007). A prehispanic (Postclassic) capital center in colonial transition: Excavations at Yucundaa Pueblo Viejo de Teposcolula, Oaxaca, Mexico. Latin American Antiquity 18: $333-353$.

Sugiyama, S. (1998). Archaeology and iconography of the censer complex: Official military emblems from the Ciudadela? Online article published at http://archaeology.la.asu.edu/vm/teo/notes/SS/ noteI_2SS.htm.

Sullivan, K. S. (2005). Making and manipulating ritual in the city of the gods: Figurine production and use at Teotihuacán, México. Online article published at http://www.famsi.org/reports/03021/ index.html.

Sullivan, K. S. (2006). Specialized production of San Martín orange ware at Teotihuacan, Mexico. Latin American Antiquity 17: 23-53.

Sullivan, K. S. (2007). Commercialization in Early State Economies: Craft Production and Market Exchange in Classic period Teotihuacan, Ph.D. dissertation, School of Human Evolution and Social Change, Arizona State University, Tempe.

Taube, K. A. (2003). Tetitla and the Maya presence at Teotihuacan. In Braswell, G. E. (ed.), The Maya and Teotihuacan: Reinterpreting Early Classic Interaction, University of Texas Press, Austin, pp. 273-314.

Terraciano, K. (2001). The Mixtecs of Colonial Oaxaca: Nudzahui History, Sixteenth through Eighteenth Centuries, Stanford University Press, Stanford, CA.

Tovalín, A., and Barba, L. (1999). Estudio químico de los pisos de una unidad habitacional en Tlalpizahuac, Estado de México. Anales de Antropología 32: 161-179.

Uruñuela, G., and Plunket, P. (1998). Áreas de actividad en unidades domésticas del Formativo Terminal en Tetimpa, Puebla. Arqueología 20: 3-19.

Uruñuela, G., and Plunket, P. (2001). "De piedra ha de ser la cama..." Las tumbas en el Formativo de Puebla-Tlaxcala y la Cuenca de México, a partir de la evidencia de Tetimpa, Puebla. Arqueología 25: $3-22$.

Uruñuela, G., and Plunket, P. (2007). Tradition and transformation: Village ritual at Tetimpa as a template for early Teotihuacan. In Gonlin, N., and Lohse, J. C. (eds.), Commoner Ritual and Ideology in Ancient Mesoamerica, University Press of Colorado, Boulder, pp. 33-54.

Vaillant, G. C., and Sanders, W. T. (2000). Excavations at Chiconautla. In Sanders, W. T., and Evans, S. T. (eds.), The Teotihuacan Valley Project Vinal Report, Vol. 5: The Aztec Period Occupation of the Valley, Pt. 2: Excavations at T.A. 40 and Related Projects, Occasional Papers in Anthropology 26, Pennsylvania State University, University Park, pp. 757-787.

van den Berghe, P. L. (1979). Human Family Systems: An Evolutionary View, Waveland Press, Prospect Heights, IL.

van der Leeuw, S. (1977). Towards a study of the economics of pottery making. In Beek, B. L., Brant, R. W., and van Watteringe, W. G. (eds.), Ex Horreo, Albert Egges van Giffen Instituut voor Prae- en Protohistorie, University of Amsterdam, Amsterdam, pp. 68-76.

Vega Nova, H. (1996). Proyecto de investigación arqueológica en Yautepec, Morelos. In Memoria, III Congreso Interno del Centro INAH Morelos a los xx años de su fundación, Instituto Nacional de Antropología e Historia, Centro Regional Morelos, Cuernavaca, pp. 149-168.

Waddell, L. A. (2007). Lhasa and Its Mysteries: With a Record of the Expedition of 1903-1904, Cosimo, New York.

Watanabe, J. M. (2004). Some models in a muddle: Lineage and house in Classic Maya social organization. Ancient Mesoamerica 15: 159-166.

Watanabe, J. M. (2007). Ritual economy and the negotiation of autarky and interdependence in a ritual mode of production. In Wells, E. C., and Davis-Salazar, K. L. (eds.), Mesoamerican Ritual 
Economy: Archaeological and Ethnological Perspectives, University Press of Colorado, Boulder, pp. 301-322.

Webb, R. W., and Hirth, K. G. (2003). Xochicalco, Morelos: The abandonment of households at an Epiclassic urban center. In Inomata, T., and Webb, R. W. (eds.), The Archaeology of Settlement Abandonment in Middle America, University of Utah Press, Salt Lake City, pp. 29-42.

Wells, E. C., and Davis-Salazar, K. L. (eds.) (2007). Mesoamerican Ritual Economy: Archaeological and Ethnological Perspectives, University Press of Colorado, Boulder.

White, C. D., Storey, R., Spence, M. W., and Longstaffe, F. J. (2004). Immigration, assimilation and status in the ancient city of Teotihuacan: Isotopic evidence from Tlajinga 33. Latin American Antiquity 15: 176-198.

Wilk, R. R., and Ashmore, W. (eds.) (1988). Household and Community in the Mesoamerican Past, University of New Mexico Press, Albuquerque.

Wilk, R. R., and Rathje, W. L. (1982). Household archaeology. American Behavioral Scientist 25: 617-639.

Williams, B. J. (1984). Mexican pictorial cadastral registers: An analysis of the Códice de Santa María Asunción and the Codex Vergara. In Harvey, H. R., and Prem, H. J. (eds.), Explorations in Ethnohistory: Indians of Central Mexico in the Sixteenth Century, University of New Mexico Press, Albuquerque, pp. 103-125.

Williams, B. J., and del Carmen Jorge y Jorge, M. (2001). Surface area computation in ancient Mexico: Documentary evidence of Acolhua-Aztec proto-geometry. Symmetry: Culture and Science 12: $185-200$.

Williams, B. J., and Harvey, H. R. (1997). The Códice de Santa María Asunción: Facsimile and Commentary: Households and Lands in Sixteenth-Century Tepetlaoztoc, University of Utah Press, Salt Lake City.

Winter, M. (2002). Monte Albán: Mortuary practices as domestic ritual and their relation to community religion. In Plunket, P. (ed.), Domestic Ritual in Ancient Mesoamerica, Cotsen Institute of Archaeology, University of California, Los Angeles, pp. 67-82.

Winter, M. (2003). Monte Albán and Late Classic site abandonment in highland Oaxaca. In Inomata, T., and Webb, R. W. (eds.), The Archaeology of Settlement Abandonment in Middle America, University of Utah Press, Salt Lake City, pp. 103-119.

Wright Carr, D. C. (2008). La sociedad prehispánica en las lenguas náhuatl y otomí. Acta Universitaria (Universidad de Guanajuato) 18: 15-23.

\section{Bibliography of recent literature}

Ávila López, R. (2006). Mexicaltzingo: arqueología de un reino culhua-mexica, Vol. 1, Instituto Nacional de Antropología e Historia, Mexico.

Burkhart, L. M. (1997). Mexica women on the home front: Housework and religion in Aztec Mexico. In Schroeder, S., Wood, S., and Haskett, R. (eds.), Indian Women of Early Mexico, University of Oklahoma Press, Norman, pp. 25-54.

Brumfiel, E. M. (2005). Opting in and opting out: Tula, Cholula, and Xaltocan. In Blanton, R. E. (ed.), Settlement, Subsistence, and Social Complexity: Essays Honoring the Legacy of Jeffrey R. Parsons, Cotsen Institute of Archaeology, University of California, Los Angeles, pp. 63-88.

Escalante Gonzalbo, P. (ed.) (2004). Historia de la vida cotidiana en México, Tomo I, Mesoamérica y los ámbitos indígenas de la Nueva España, El Colegio de México, Fondo de Cultura Económica, Mexico City.

Finsten, L. (1995). Jalieza, Oaxaca: Activity Specialization at a Hilltop Center, Publications in Anthropology No. 48, Vanderbilt University, Nashville, TN.

García, R., Ramírez, F., Gámez, L., and Córdoba, L. (1998). Chimalhuacan: rescate de una historia, Instituto Nacional de Antropología e Historia, Toluca, Mexico.

Guevara Chumacero, M. (2004). El Edificio 3 de Tula. Historia de un palacio? Ciencia Ergo Sum 11: $164-170$.

Hare, T. S. (2000). Between the household and the empire: Structural relationships within and among Aztec communities and polities. In Canuto, M. A., and Yaeger, J. (eds.), The Archaeology of Communities: A New World Perspective, Routledge, New York, pp. 78-101. 
Hendon, J. A. (2000). Having and holding: Storage, memory, knowledge, and social relations. American Anthropologist 102: 42-53.

Hendon, J. A. (2002). Social relations and collective identities: Household and community in ancient Mesoamerica. In O'Donovan, M. (ed.), The Dynamics of Power, Center for Archaeological Investigations, Southern Illinois University, Carbondale, pp. 273-300.

Inomata, T., and Webb, R. W. (eds.) (2003). The Archaeology of Settlement Abandonment in Middle America, University of Utah Press, Salt Lake City.

Lazcano Arce, J. C. (1998). Exploraciones arqueológicas en Cacaxtla: Plaza de los Tres Cerritos. In Brambila, R. (ed.), Antropología e historia del occidente de México, XXIV Mesa Redonda de la Sociedad Mexicana de Antropología, Mexico, pp. 1733-1749.

Lazcano Arce, J. C. (2002). Modo de vida y explotación de recursos naturales. In Brambila, R. (ed.), XIV Coloquio de Historia Canario-Americana, Ediciones del Cabildo de Gran Canaria, Las Palmas, Spain, pp. 348-360.

López Wario, L. A. (1993). Ecatepec: hace 2600 años. In Castillo Mangas, M. T. (ed.), A propósito del Formativo, Subdirección de Salvamento Arqueológico, Instituto Nacional de Antropología e Historia, Mexico, pp. 85-92.

Manzanilla, L. (ed.) (1993). Anatomía de un conjunto residencial teotihuacano en Oztoyahualco, Vols. I and II, Instituto de Investigaciones Antropológicas, Universidad Nacional Autónoma de México, Mexico City.

Morelos García, N. (1993). Proceso de producción de espacios y estructuras en Teotihuacan, Serie Arqueología, Colección Científica 274, Instituto Nacional de Antropología e Historia, Mexico.

Neff, H., Glascock, M. D., Charlton, T. H., Otis Charlton, C., and Nichols, D. L. (2000). Provenience investigation of ceramics and obsidian from Otumba. Ancient Mesoamerica 11: 307-321.

Noyola Cherpitel, A. (1992/1993). Unidades habitacionales prehispánicas excavadas en el Estado de Puebla. Notas Mesoamericanas 14: 19-36.

Pollard, H. P. (1996). La transformación de elites regionales en Michoacán central. In Williams, E., and Weigand, E. (eds.), Las cuencas del occidente de México: época prehispánica, Cologio de Michoacán and Centre d'Etudes Mexicaines et Centre-Americaines, Zamora, Michoacán, Mexico, pp. 131-156.

Pollard, H. P, and Cahue, L. (1999). Mortuary patterns of regional elites in the Lake Patzcuaro Basin of Western Mexico. Latin American Antiquity 10: 259-280.

Rattray, E. C. (2003). The Teotihuacan-Oaxaca relationship. In Plunket, R. (ed.), Homenaje a John Paddock, Universidad de las Américas - Puebla, Cholula, pp. 139-147.

Rosenswig, R. M. (2000). Some political processes of ranked societies. Journal of Anthropological Archaeology 19: 413-460.

Sempowski, M., and Spence, M. W. (eds.) (1994). Mortuary Practices and Skeletal Remains at Teotihuacan, University of Utah Press, Salt Lake City.

Serra Puche, M. C. (1998). Xochitécatl, Gobierno del Estado de Tlaxcala, Tlaxcala.

Serra Puche, M. C. (2000). Identidad en Xochitécatl, Tlaxcala, Mexico. Estudios de Cultura Otopame 2: 15-27.

Serra Puche, M. C. (2005). Xochitécatl y sus volcanes: pasado y presente. In Vargas Pacheco, E. (ed.), IV Coloquio Pedro Bosh Gimpera: El occidente y centro de México, Universidad Nacional Autónoma de México, Mexico City, pp. 331-347.

Serra Puche, M. C., Lazcano Arce, J. C., and Torres Sanders, L. (2001). Actividades rituales en Xochitécatl-Cacaxtla, Tlaxcala. Arqueología 25: 71-88.

Soler-Arechalde, A. M., Sánchez, F., Rodríguez, M., Caballero-Miranda, M., Goguitchaishvili, A., Urrutia-Fucugauchi J., Manzanilla, D., and Tarling, D. (2006). Archaeomagnetic investigations of oriented pre-Columbian lime plasters from Teotihuacan, Mesoamerica. Earth, Planets and Space 58: 1433-1439.

Storey, R. (1992). Life and Death in the Ancient City of Teotihuacan: A Modern Paleodemographic Synthesis, University of Alabama, Tuscaloosa.

Weigand, P. C. (1996). The architecture of the Teuchitlan tradition of the Occidente of Mesoamerica. Ancient Mesoamerica 7: 90-101. 